\title{
MEMBRi AI FAMILIEI CORBEANU ŞI ALE LOR MORMINTE DIN FOSTA BISERICĂ A MĂNĂSTIRII CĂTĂLUI
}

GEORGE TROHANI ${ }^{1}$

\section{REZUMAT:}

Studiul de față reprezintă o republicare, în condiții tipografice net superioare, a vechilor săpături arheologice din anii 1965-1967, 1977 și 1988, privind în special mormintele aparținând membrilor familiei Corbeanu.

Se insistă în prezentarea obiectelor de podoabă, a bijuteriilor și fragmentelor de veșminte - descoperiri făcute în special în cavoul 4 atribuit Mariei Corbeanu-Herescu, prima soție a bine cunoscutului om politic și de cultură Udriște Năsturel Herescu, fratele Doamnei Elena (soția domnitorului Matei Basarab) și mama viitorului principe Mateiaş, adoptat de cuplul voievodal după decesul prematur al mamei sale în 1635.

\section{Résumé: Membres de la famille Corbeano et leurs tombes De l'anCienne ÉGLise du MONASTÈRE CĂTĂLUI}

La présente étude représente une republication, dans des conditions typographiques notamment supérieures des anciennes fouilles des années 1965-1967,1977 et 1988, concernant surtout les tombes appartenant aux membres de la famille Corbeano.

On insiste sur la présentation des objets de parure, des bijoux et des fragments des vêtements - découvertes spécialement faites dans le caveau no. 4 attribué Maria Corbeano-Heresco, la première épouse du bien connu homme politique et de lettre Udriste Nasturel Heresco, frère de la princesse Hélène (épouse du prince Mathieu Basarab) et mère du futur prince Mateiaș, adopté par le couple princier après le décès prématuré de sa mère en 1635.

CUVINTE CHEIE: Cătălui, Corbeanu, îmbrăcăminte, bijuterii, obiecte de podoabă.

MoTS CLÉFS: Cătălui, Corbeano, vêtements, bijoux, objets de parure.

În cele de față dorim o republicare a celor prezentate anterior privind săpăturile arheologice din anii 1965 - 1967, conduse de profesorul Gheorghe Cantacuzino (1900 - 1977), precum și ale noastre din 1977 și 1988 de pe panta dealului Tufele Grecului, situat la est de comuna Căscioarele (actualmente jud. Călărași), unde au fost descoperite ruinele fostei Mănăstiri Cătălui (Fig. 1-4).

Ideea ce ne-a călăuzit la această reluare a fost dorința de prezentare în condiții grafice net superioare a obiectelor publicate cu jumătate de secol în urmă².

Mai întâi, pentru readucere aminte, facem un scurt rezumat a celor publicate până acum: Biserica mănăstirii a fost ridicată puțin înainte de 7 iulie 1577 și a fost concomitent înconjurată cu ziduri, fiind transformată în mănăstire. Zidurile înconjurătoare, groase de circa $1 \mathrm{~m}$, alcătuite din blocuri masive de piatră și cu puține cărămizi erau prevăzute în colțul de SV şi probabil și în cel de NE cu câte o poartă. În incintă se includea și clădirea ce servea drept locuință, transformată în stăreție și chilii. În afara zidurilor se afla satul dependent de mănăstire precum și cimitirul.

1 Articol elaborat cu ajutorul desenatoarelor Georgiana Ducman, Simona Movilă și Raluca Teodoru-Arnăutu.

2 Cantacuzino,Trohani 1979, 261-328; Trohani, Damian, Sârbu 1995, 233-257; Theodorescu 1979, 168-179; Theodorescu 1968, 2, 213-220; Sturdza 2018, 257-271. 
În evoluția aşezământului, în special a bisericii, s-au putut constata mai multe faze și subfaze de construcție și utilizare. De asemenea, s-a constatat că încă din prima fază, de la începutul viețuirii pe acest loc, în a doua jumătate a secolului al XVI-lea, s-au practicat primele înmormântări - mai întâi la vest de biserică și la nord de incintă.

Din documente reiese că printre primii înmormântați în incinta mănăstirii, la a cărei întemeiere a contribuit și ea, a fost monahia Maria din Florești și Clătești, decedată prin anii 1577-1579, călugărită după decesul soțului ei, Teodosie din Periș (omorât în 1547). Ea era mama jupaniței Caplea.

Înmormântări s-au efectuat și în interiorul pronaosului bisericii. Este vorba de ctitorii așezământului. Pe latura de sud a pronaosului se afla cavoul nr. 1, de formă trapezoidală (1,80 x 0,40-0,76 m și adânc de $0,78 \mathrm{~m})$ având pereții din cărămidă. În partea superioară se afla un capac de cărămidă acoperit cu o lespede dintr-o gresie calcaroasă și prevăzută cu o inscripție în slavonă: ,(+ a răposat robul lui Dumnezeu, jupan Stan mare spătar), în zilele binecinstitorului și de Hristos iubitorului domn, Ion Mihnea, voievod, în anul 7090 (=1582), în (luna ...)" (probabil către sfârșitul intervalului 1 ianuarie - 31 august 1582)3 (Fig. 5 a). La sfârșitul fazei a doua a bisericii (1689) cavoul a fost jefuit și osemintele împrăștiate, rămânând in situ doar tibiile. În pământul de umplutură s-au descoperit câteva fragmente dintr-o stofă groasă, de culoare maronie, ce trebuie să fi provenit de la o mantie (Fig. 5 b).

Pe latura de nord a pronaosului se afla mormântul (Biserică) nr. 1 (1,87 x 0,70 m și adânc de 0,90 m). Jefuit în 1689, reprezintă mormântul pe a cărei lespede funerară scria în slavonă: ,+ A răposat roaba lui Dumnezeu, jupanița Caplea, în zilele lui Ștefan v(odă fiul lui Io)n voievod, luna mai, 9 zile, în anul 7099”' (= 1591). Lespedea, dintr-o gresie calcaroasă, a fost descoperită în fața pronaosului, unde a fost mutată după jefuirea bisericii și utilizată drept treaptă (Fig. 6) .

Sfârșitul primei faze de existență a mănăstirii se fixează în perioada 1595 - 1608, datorându-se evenimentelor politico-militare din perioada domniilor lui Mihai Viteazul (1593-1601) și Radu Şerban (1601, 1602-1610).

A doua fază din evoluția mănăstirii cuprinde perioada dintre primul deceniu al secolului al XVII-lea și începutul domniei lui Constantin Brâncoveanu, mai precis anul 1689. Bisericii i se adaugă un nou altar precum şi un nou pronaos (exonartex) în continuarea celui vechi, dar puțin lărgit. Lungimea bisericii atinge acum 17,75 m la interior și 19,30 m la exterior.

Zidurile sunt ridicate doar din cărămidă cu mortar şi grinzi de lemn ca întăritor. Pe latura de vest a incintei, lângă poarta din colțul de SV se ridică un turn-clopotniță ce servea și drept poartă. Construit din cărămizi legate între ele cu mortar, iar pe alocuri prevăzut cu bolovani mari din calcar, avea drept întăritori grinzi de lemn. De formă rectangulară (6,90 / 7 x 4,26 / 4,54 m) era înalt de circa 4 m. Trecerea pe sub el se făcea printr-o încăpere boltită străjuită la intrare și ieșire de câte o arcadă. Latura de nord a incintei se dezafectează, ridicându-se pe locul ei o clădire din cărămizi și prevăzută cu mai multe încăperi. Prin aceasta incinta mănăstirii s-a mutat mai spre nord cu 3,60 m.

Unele construcții se ridică la est de incinta răsăriteană, în colțul de SE al incintei și la vest de locuința stăreție. În același timp se constată că unele ziduri se tencuiesc atât la interior cât și la exterior.

În privința cimitirului se constată o predilecție pentru zona din jurul zidului de nord al incintei. Unele morminte sunt situate însă şi în interiorul incintei - majoritatea la nord de biserică și doar câteva la sud de ea. Mormintele din interiorul incintei trebuie să reprezinte persoane cu un anumit rol în viața mănăstirii, adică călugări al căror cap era depus pe o cărămidă - M. 1 de la vest de biserică, cu capul pe o perniță din pământ tare, datat cu o para emisă la Cairo în 1695; M. 4 la sud de naos, cu o cărămidă sub cap; M. 45 la nord de pronaos, sub craniu trei cărămizi, iar sub bazin și sub tibii câte o cărămidă; M. 48 tot la nord de pronaos, pe cap o cărămidă susținută de alte două pe laturi; sau M. 57 de asemenea la nord de pronaos, pe un pat de cărămizi dar având, probabil, un pinten la unul din picioare.

Alte morminte, prin piesele de inventar ce le conțineau, par a fi aparținut unor persoane cu un anumit rol în viața comunităţii în perioada cuprinsă între mijlocul sec. XVII - sfârşitul sec. XVIII - M. 5, din zona de sud-est, cu trei monete și fragmente de țesătură în zona omoplaților; M. 41, din zona de est, cu patru monete, un inel și țesătură cu paiete; M. 42, tot din zona de est, cu șase monete și un șnur cu paiete în jurul capului, iar la gât un colier de mărgele de sticlă verde și roșie; M. 47 B, la nord de pronaos, cu un inel sigilar din argint la degetul inelar de la mâna stângă; M. 61, în zona de vest, copil cu cercel din sârmă de cupru, cu șatonul răsucit în opt și închizând o piatră verzui-albăstruie, la urechea stângă.

Rudele ctitorilor sunt însă înmormântate la intrarea în biserică. Astfel, în partea de NV a noului pronaos se afla cavoul nr. 2 făcut din cărămizi și prevăzut cu un capac tot din cărămizi. De formă dreptunghiulară $(1,52$ x 0,62 m şi adânc de 0,85 m) conținea oasele unui copil depus într-un coșciug din lemn de pin (Fig. 7 a-c).

\footnotetext{
3 Cantacuzino, Bălan 1968, 547-553 (549-550, fig. 2/3).

4 Cantacuzino, Bălan 1968, 552, fig. 3/1.
} 


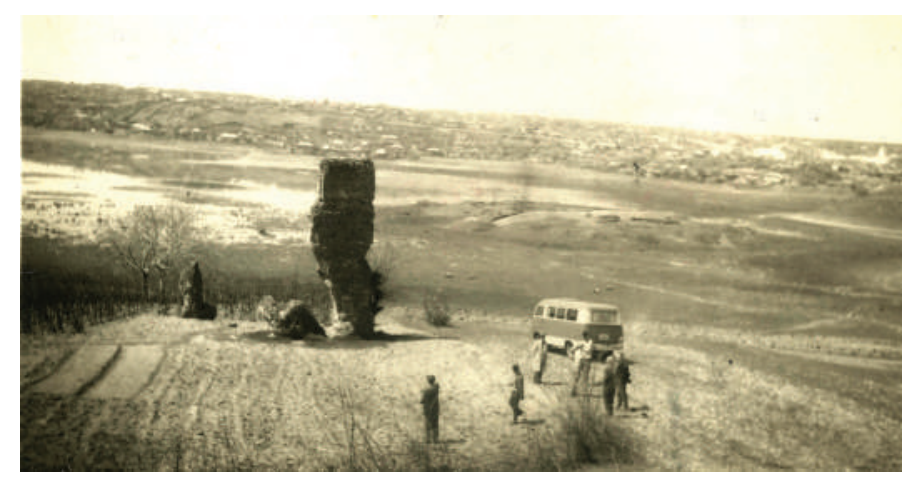

Figura 1. Vedere generală, de la est spre vest, a locului pe care se afla Mănăstirea Cătălui. În plan îndepărtat comuna Căscioarele, jud. Călărași. În centru așezarea neolitică Ostrovel. 25 aprilie 1965.

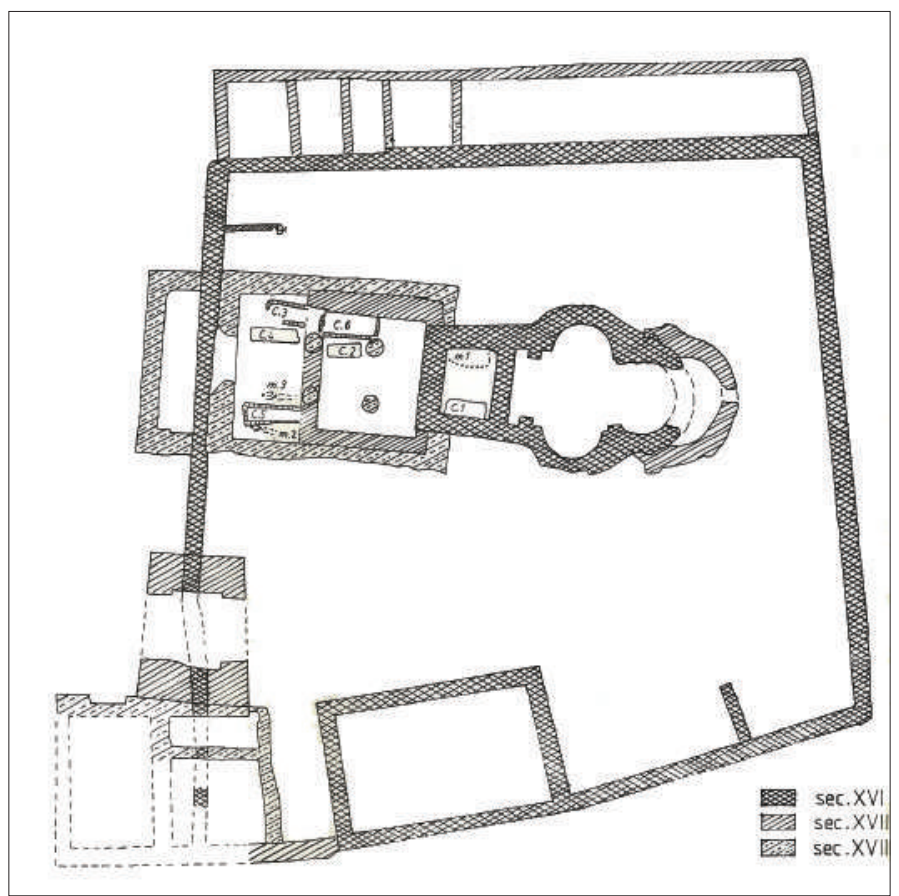

Figura 2. Planul de ansamblu al fostei Mănăstiri Cătălui pe baza cercetărilor arheologice din anii 1965-1968, 1977 și 1988.

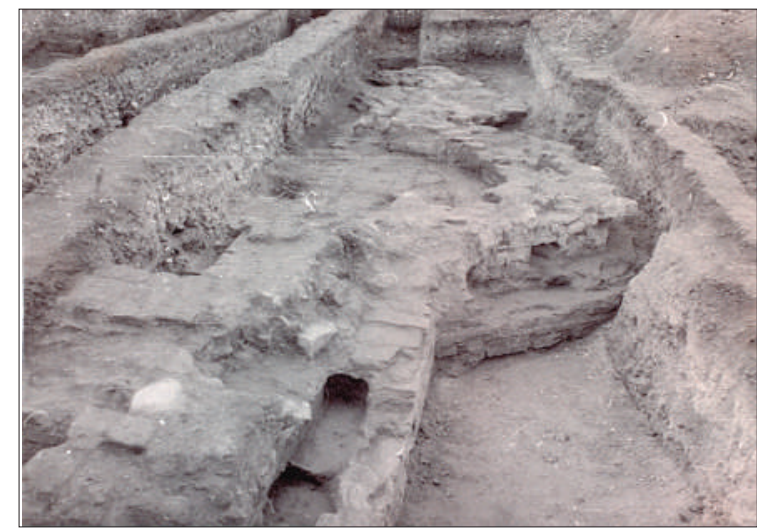

Figura 3. Partea de sud a Bisericii Mănăstirii Cătălui. Cercetare toamna 1965 .

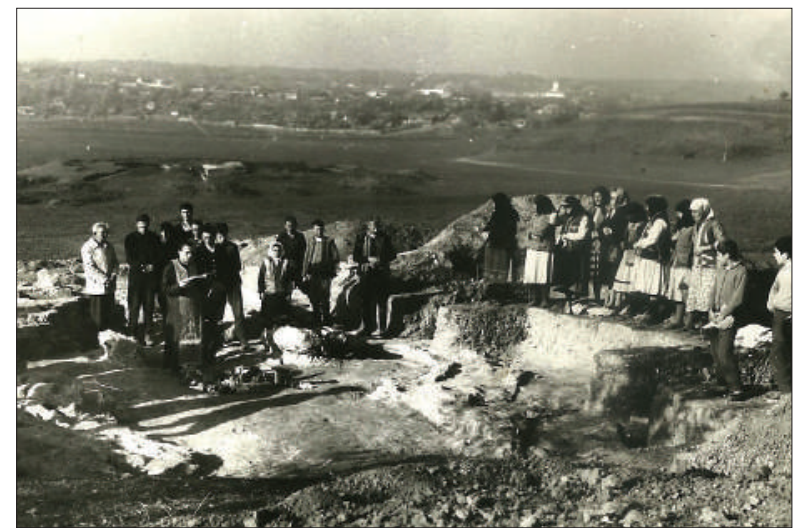

Figura 4. Slujbă de pomenire a ctitorilor, a celor înmormântați în cimitirul din jurul bisericii, precum și a truditorilor pe șantierul arheologic. 16 noiembrie 1967. 
În afara bisericii, din primele două faze ale existenței ei, la stânga și în dreptul intrării, se afla cavoul nr. 4, iar la dreapta, pandant, cavoul nr. 5. Acesta din urmă, de formă trapezoidală $(\mathrm{L}=2,60 \mathrm{~m}$., lăț $0,68 \mathrm{~m}$ la est și $0,84 \mathrm{~m}$ la vest) cu fundul din pământ (la $-0,65 \mathrm{~m}$ sub capacul boltit), era construit din cărămizi așezate pieziș pe margini și pe cant în centru (13 rânduri). Capacul se afla la $-0,52 \mathrm{~m}$ sub solul actual, iar partea sa de vest era distrusă, fiind jefuit la sfârşitul fazei a II-a (Fig. 8).

Sfârșitul fazei a doua din evoluția mănăstirii este pus în legătură cu evenimentele din 1689 când pătrund în Țara Românească trupe austriece comandate de generalul Heissler ${ }^{5}$, iar Mănăstirea Cătălui a fost jefuită de tătari ,făr de veste, de au luat ce au găsit, dobitoacele și arginturile mănăstirii și toate cărțile ce au avut de moșie, iar după aciasta, în urma tătarilor, eșind călugării de unde au fost fugiți din baltă, aflat-au cărțile de moșie ale mănăstirii risipite și fărămate ...”.

Constantin Brâncoveanu, reușind să instaureze liniștea, se poate spune că după aceste evenimente din 1689/1692 începe faza a III-a și ultima din evoluția Mănăstirii Cătălui ce va dura până la începutul secolului XIX.

Biserica capătă dimensiuni considerabile (25 m lungime la interior și $26,80 \mathrm{~m}$ la exterior), iar în noul pronaos, mult mărit, sunt incluse toate cavourile şi mormintele ce anterior se aflau în afara bisericii, la vest de ea, precum și unele noi.

Astfel, în colțul de nord-vest al noului pronaos în primii ani din această fază - sfârșitul secolului XVII - începutul secolului XVIII - se construiește cavoul nr. 3 (de formă dreptunghiulară, 2,36 x 0,80 m și adânc de $0,74 \mathrm{~m}$, conținând 10 asize de cărămizi și un capac boltit, tot din cărămizi) (Fig. 9) în care a fost depus într-un coșciug de lemn o adultă la a cărei mână dreaptă se afla prins un inel cu verigă din aur și cu şatonul triunghiular cu diamant tetraedric (Fig. 10 a-c). Redăm, în continuare, descrierea piesei aşa cum figurează în actele Muzeului Național de Istorie a României.uraInel cu diamant - nr. inv. 11.314 - Căscioarele; Au 728/1638; G = 3,05 gr. Șatonul, în
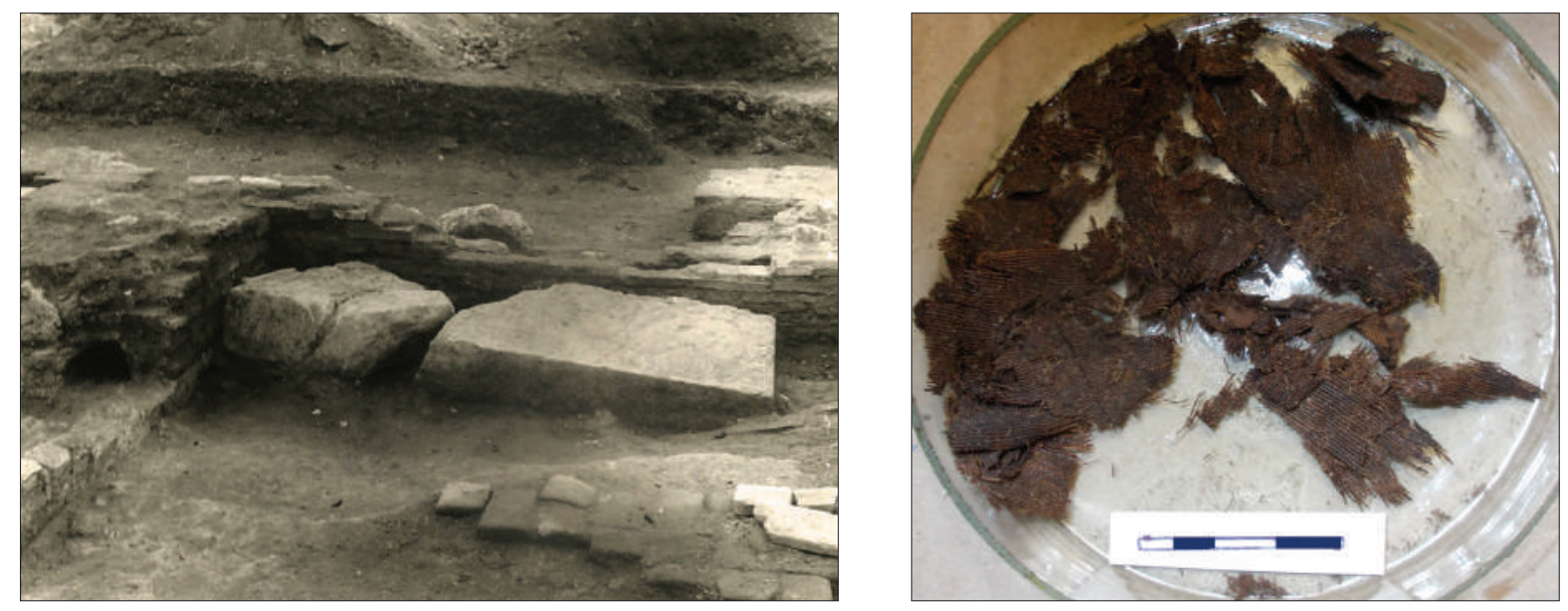

Figura 5. a - Piatra de mormânt a lui Stan Spătarul de pe cavoul nr. 1. 1967; b - fragmente de stofă din pământul de umplutură.

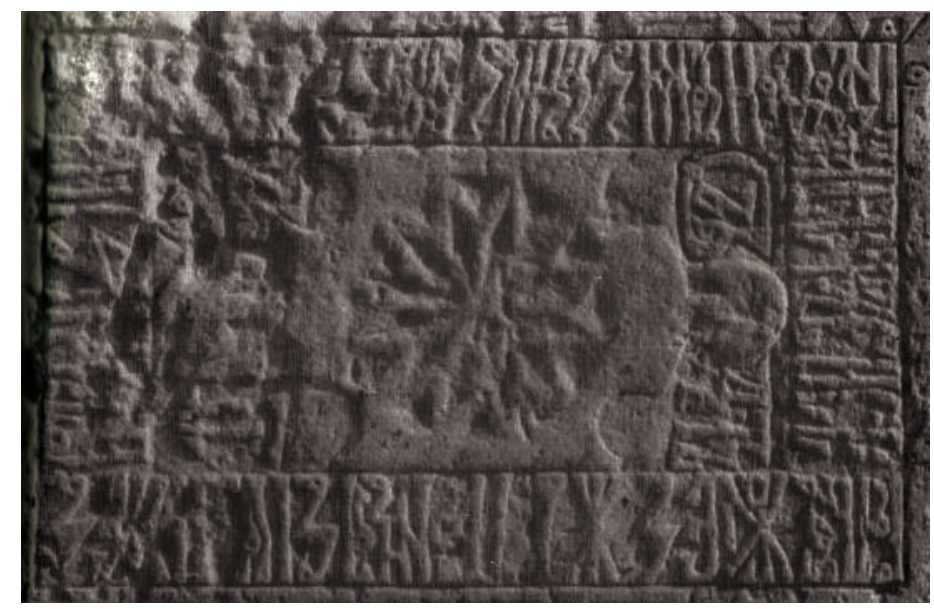

Figura 6. Lespedea funerară a jupaniței Caplea. 1967.

\footnotetext{
5 Theodorescu 1979, 168-179.
} 
a
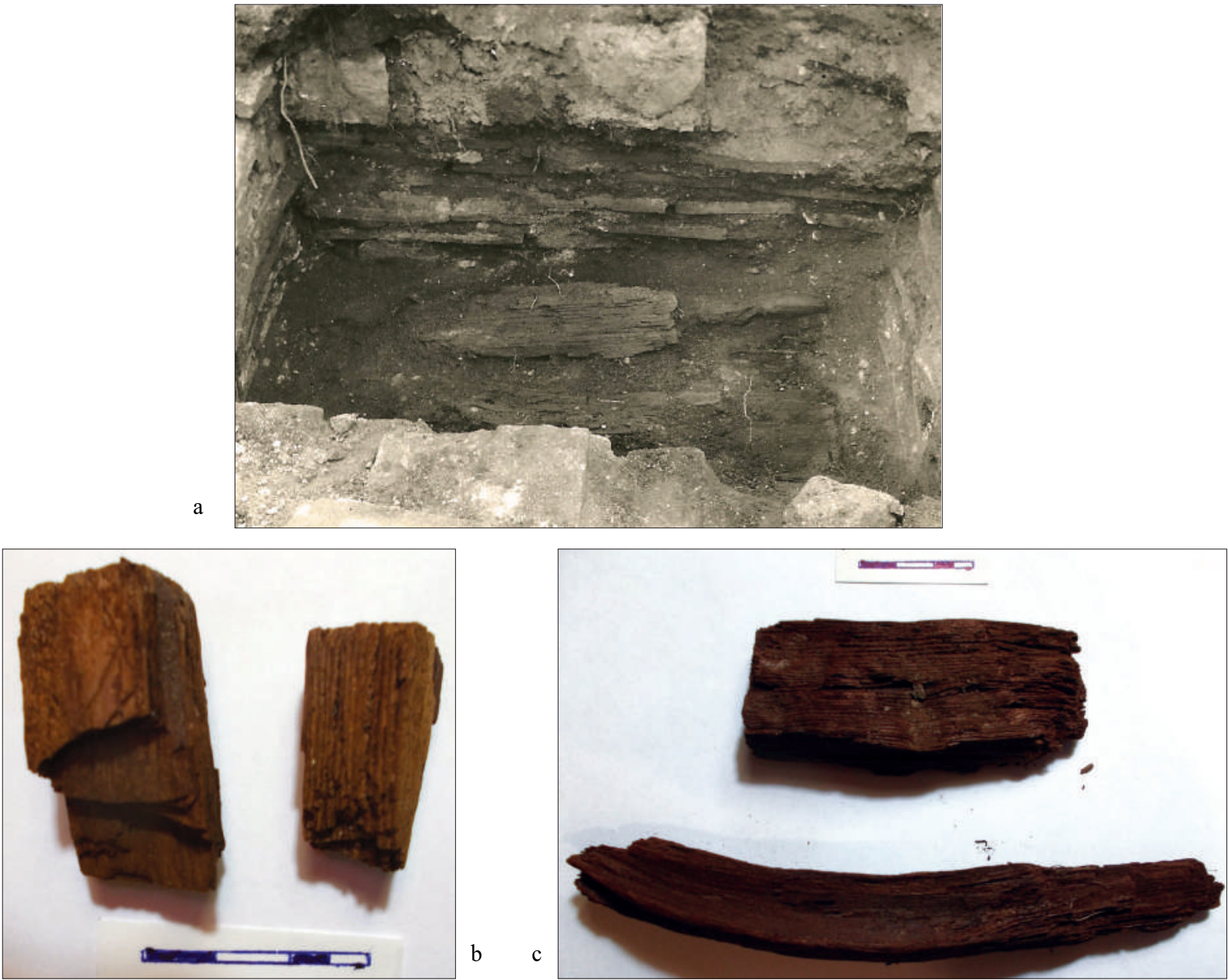

Figura 7. a - Cavoul nr. 2, mormântul unui copil, fundul cosciugului din lemn de pin. 1967; b-c - bucăţi de lemn de pin din cosciug.

urormă de trunchi de piramidă triunghiulară, turnat odată cu veriga simplă, are montat un diamant fațetat. În partea opusă șatonului, veriga prezintă o mică proeminență ascuțită. Piesa zgâriată, lovită, piatra ciobită și de asemenea zgâriată; pe piesă urme de material străin. L max. $=23,6 \mathrm{~mm} ; \varnothing=18,6 \mathrm{~mm}(\mathrm{G}=3,00$ gr.) Au $583 \%$ (conform buletinului de analiză BNRSR 18030/1980). G=3,04 g.

La nord de cavoul nr. 2, în pronaosul din faza a II-a (secolul XVII), săpăturile din 1988 au identificat cavoul nr. 6 ce avea o formă rectangulară $(2,32$ x $0,80 \mathrm{~m}$ și adânc de $0,90 \mathrm{~m})$. In el se aflau osemintele unui personaj principal, depus în poziția decubit dorsal, iar la stânga și dreapta sa, prin reînhumare dar în poziție anatomică, resturile osoase a doi copii.

Conținutul acestui cavou corespunde întocmai cu cele menționate - în limba română cu slove chirilice - pe o mare piatră funerară, descoperită cu ani în urmă (înaintea efectuării săpăturilor arheologice) , + Supt această peatră zacu oasele / banului Teodosie s(i)nu Vintilă vornecul și săau pristăvit în oraș în Bucureșt(i), în luna lui iunie 22 dni. Și la capul petrei, / den sus, zacu osele a doi coconi, a lui Gheorghi / și Teodosie; în zele(l)i domnului Ion Matei Băsărab vo(ie)vod. Și această petră pusă de jupăneasă Hrisosculina bănesa, al răposatului Tiodosie banul'. Iar în final, în slavonă: ,scris în luna aprilie 24 zile, in leat $7156^{\prime 6}{ }^{\prime}(=1648)$, deci la zece luni după decesul din 22 iunie 1647 a marelui ban Teodosie Corbeanu (Fig. 11 a-b; 12).

În pământul de umplutură al cavoului, pe lângă o monetă de jumătate de grosz polonez din argint emis în timpul regelui Cazimir IV (1444-1492), era aruncat un inel-sigiliu din aur ce are veriga și baza șatonului decorată cu motive vegetale de culoare albă și verde închis, obținute prin tehnica in niello. Şatonul, ce se continuă direct din verigă, este rotund și conține în centru, incizată, o cruce greacă înconjurată de legenda circulară, în negativ, XPICOCKOY(li)HA adică Hrisoscoulina? (Fig. 13 a-c).

\footnotetext{
6 Cantacuzino, Bălan 1968, 553, fig. 3/2.

7 Trohani, Damian, Sârbu 1995, 236, f.7, 14. Inelul se află la Muzeul Civilizației Gumelnița din Oltenița, instituţie ce a finanțat săpăturile arheologice.
} 


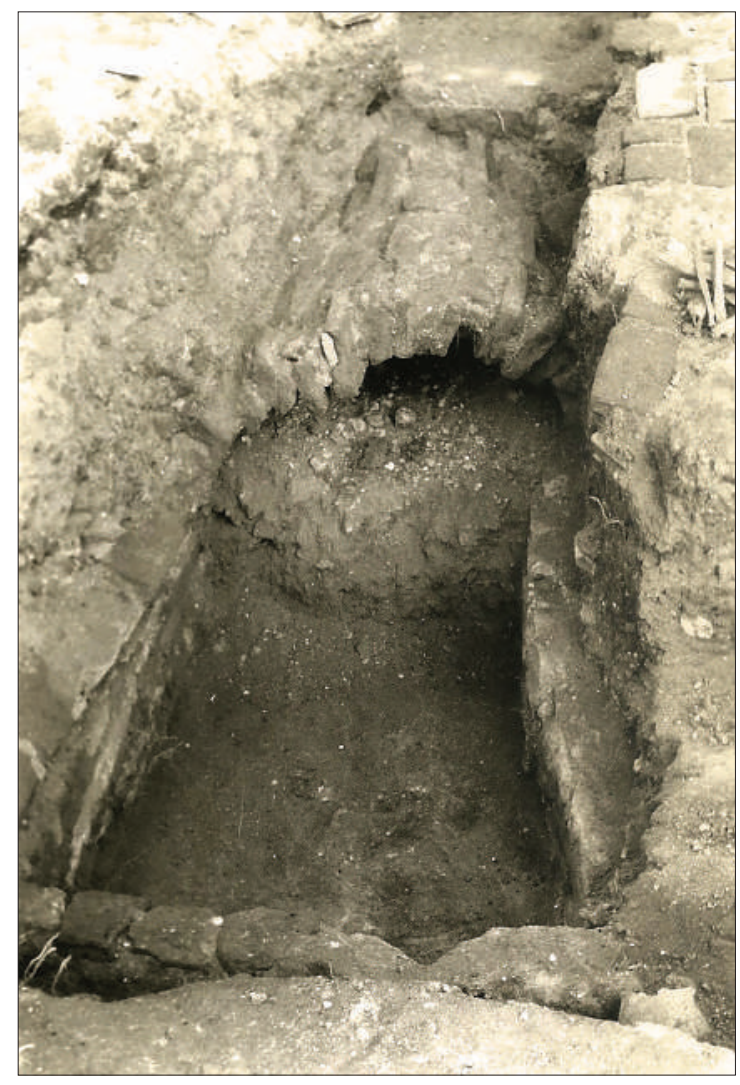

Figura 8. Cavoul nr. 5, jefuit din vechime, 1967.

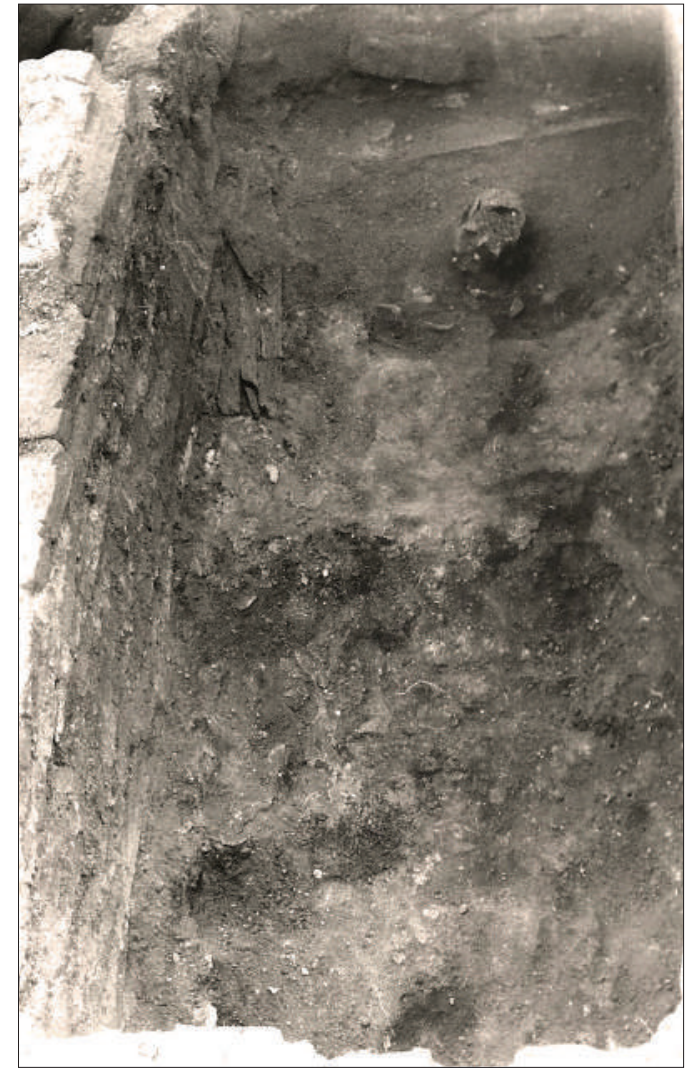

Figura 9. Cavoul nr. 3. 1967.
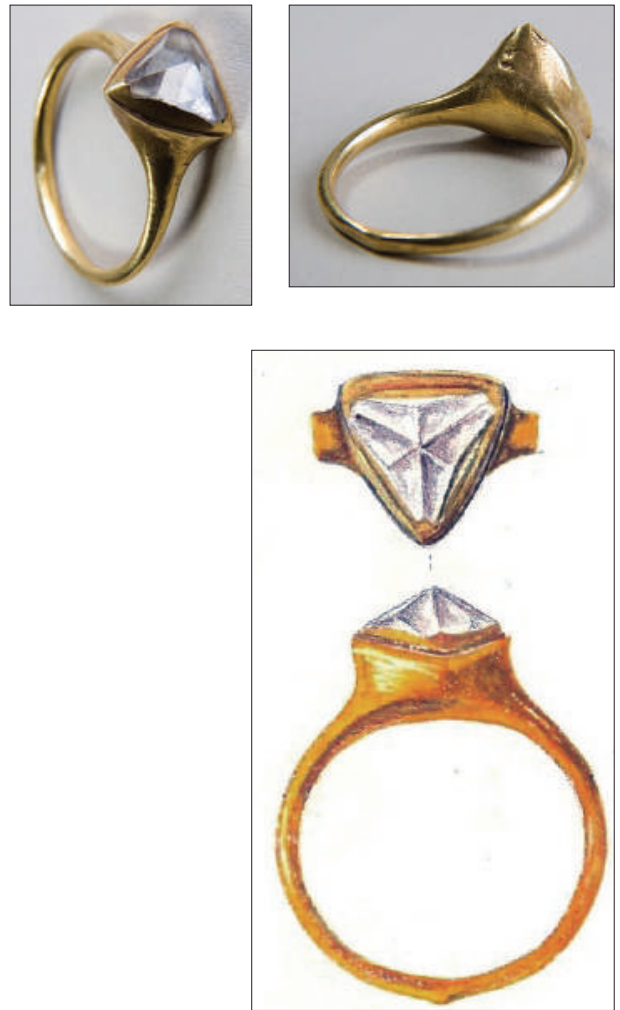

Figura 10. Inel de aur din cavoul nr. 3: a) fața, b) spatele, c) desen (Elena Becheș, 1968) 
Asemănătoare ca tehnică de execuție și decorare, ca destinație și ca perioadă de folosire sunt ,inele(le) domnești” descoperite în mormintele din Biserica „Sfinții Trei Ierarhi” din Iași ce au aparţinut Doamnei Tudosca (1600 - 1639) (Fig. 14 a-b), prima soție a lui Vasile Lupu (1595 - 1661), și lui Ioan Vodă (1625 - 1639), fiul celor doi (Fig. 15 a-b).

Aici este cazul a fi menționat un potir din argint aurit, provenind de la Mănăstirea Dintr-un lemn (jud. Vâlcea), aflat la Muzeul Național de Artă al României (inv. M 28), cu inscripția în slavonă, în relief : „, Pomenește, Doamne, sufletul robilor lui Dumnezeu, Theod(o)sie, și jupanița lui, Hrisosculina”. Artizanul este meșterul Daniel Bloweber, iar datarea este din perioada $1628-1648^{8}$ (Fig. 16).

În colțul de sud-vest al pronaosului, suprapunând în parte cavoul nr. 5, s-a aflat mormântul nr. 2 datând de la sfârşitul secolului XVII - începutul secolului XVIII şi conținând un înhumat cu mâinile pe abdomen. La mâna dreaptă s-a descoperit o monetă osmană de o para, perforată, ilizibilă. Pe piept s-au identificat mici fragmente de stofă cu bumbi de bronz, provenind de la îmbrăcămintea celui decedat (Fig. 17 a-b, Pl. II).

La nord de cavoul nr. 5 se afla mormântul (Biserică) nr. 3 conținând un înhumat cu o reînhumare la cap. Mormântul datează din prima jumătate al secolului al XVIII-lea.

Toate noile ziduri sunt ridicate doar din cărămizi prinse cu mortar. Pe baza fragmentelor de frescă descoperite în interiorul bisericii s-a putut stabili că el era decorat. În privința exteriorului el era decorat cu cărămizi ce aveau unul din capete triunghiular sau concav. Acoperișul era cu olane. Intrarea în biserică se făcea atât prin vest cât și prin două uși situate în colțurile de SV și NV ale bisericii. Interiorul era pavat cu cărămizi și dale.

În privința descoperirilor din cavoul nr 4 - cercetat în luna octombrie 1967 - s-a constatat că din mormânt, în afara bisericii, în faza a II-a, a fost înglobat în pronaosul din faza a III-a a bisericii (Fig. 18 a-j). De formă dreptunghiulară, are lungimea maximă la exterior de $2,20 \mathrm{~m}$ (pe zidul nordic) și lățimea de $0,72 \mathrm{~m}$ (est) - 0,76 m (vest). Zidurile, păstrate fragmentar, erau alcătuite din cărămizi ( 5 rânduri zidul de nord, 6 cel de vest) așezate orizontal și în lung (24-26 x 12-13 x 3-4,5 cm). Rosturile erau de 3-4 cm înălțime.

Pe fundul cavoului se aflau două şiruri a câte trei cărămizi: unul sub omoplații persoanei înmormântate, iar al doilea sub tibii.

La 0,70 m deasupra fundului se afla capacul boltit alcătuit din 16 cărămizi pe rând, așezate pieziș, pe cant, câte 8 de fiecare parte a cheii compuse din mortar. Creștetul bolții, puțin adâncit, era acoperit cu un pământ adus, peste care se afla la 0,20-0,23 m pavajul pronaosului nou al bisericii.

În interior s-au descoperit osemintele omenești ale unei adulte depuse într-un coșciug de lemn. S-au păstrat câteva piroane de fier cu urme din lemnul coșciugului.

De o deosebită importanță şi valoare sunt însă obiectele de inventar - podoabele și fragmentele de îmbrăcăminte - descoperite în mormânt.

Din documente și reprezentări artistice se știe că femeile măritate, în secolele XVI-XVII, poartă pe cap un văl de mătase, lung până la mijlocul spatelui obișnuit alb, uneori roșu (Sucevița), albastru (paraclisul Mănăstirii Bistrița, pictură reprezentând primirea moaștelor Sf. Ioan cel Nou de la Suceava, Doamna lui Alexandru cel Bun) sau verde (Voroneț şi Humor), cu dungi la capete. Lucrat din borangic, in sau bumbac, vălul acoperea tot părul. Este întâlnit în special în Moldova, unde este numit mesal, canovăț sau maramă.

La capete vălul era decorat cu mici aplice de aur, cum este cazul și la Cătălui, denumite „fluturi”. Uneori vălurile erau tivite pe o singură latură cu un galon îngust de $1 \mathrm{~cm}$., brodat cu fir aurit (Cătălui şi Dragomirna). Sunt foarte fine și lasă în transparență să se vadă părul și salbele de mărgăritare de la gât.

Peste văl putea fi pusă o bonetă sau fruntar împletit, din argint aurit și rozete, care au la mijloc pietre9. Pe capul M. 42, din zona de la est de biserică, s-au descoperit urme de țesătură cu șnur împletit și paiete; la gât colier de mărgele de sticlă verde și roșie. Monetele datează din prima jumătate a secolului XVIII (Fig. 17 d, Pl. II).

La nord de acest mormânt se află M. 41, dar datând de pe la mijlocul secolului XIX, care conține și el, în zona umerilor și pieptului, urme de țesătură, şnururi cu paiete şi monete otomane (Fig. 17 c, Pl. II).

La Cătălui, în zona capului, care inițial era depus pe o perniță, s-au descoperit 17 ace de păr ce împodobeau o maramă. Acele, din argint aurit (800 o/oo Ag), sunt alcătuite dintr-o tulpină ascuţită la capătul inferior şi o steluţă la cel superior. Steluța se compunea din trei petale triunghiulare cu email albastru, despărțite între ele de trei discuri

\footnotetext{
8 Elian et al. 1965, 656-657, nr. 938.

9 Nicolescu 1970, 167-172, fig. 62-72, 78.
} 

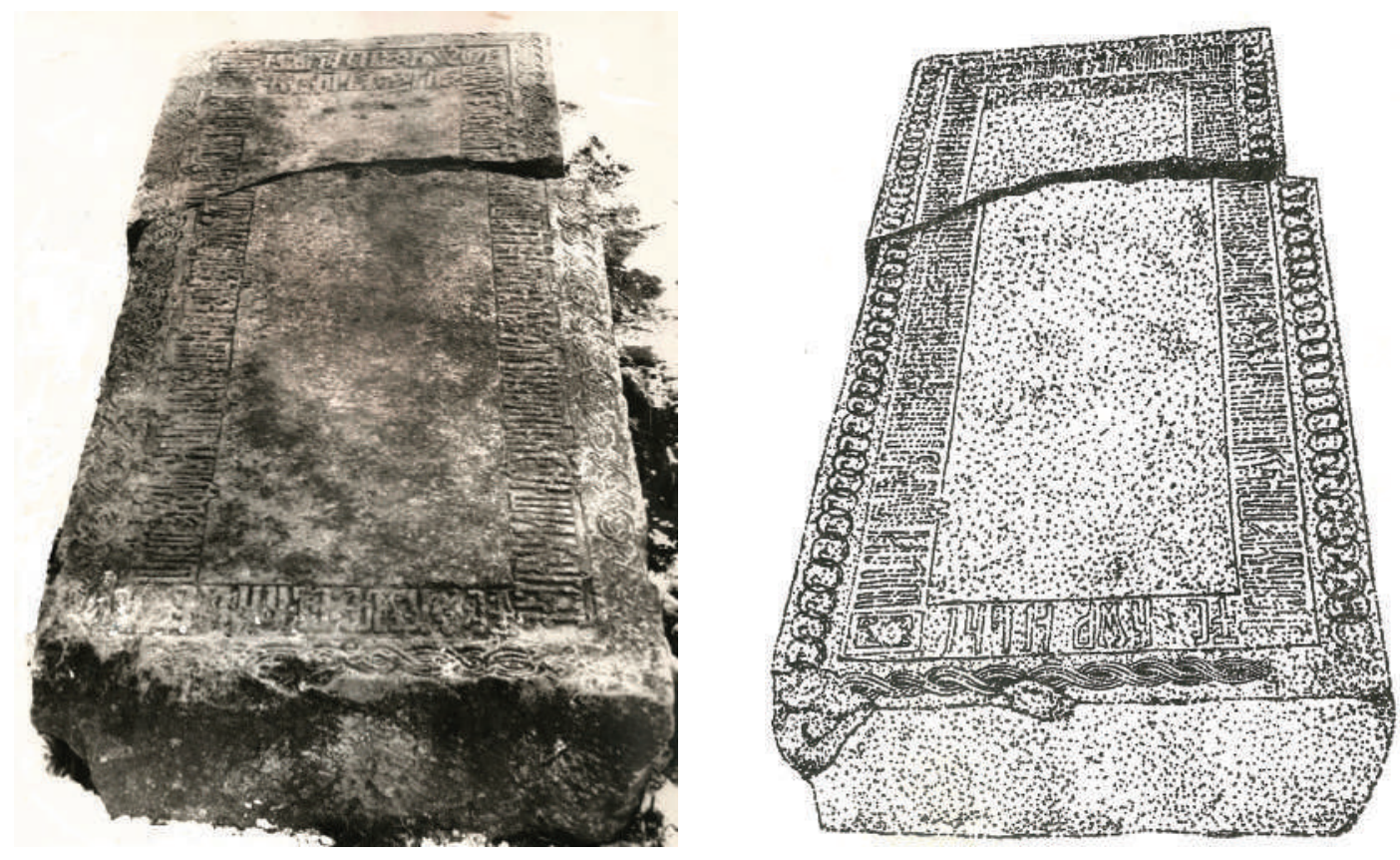

Figura 11. a - Lespedea funerară a marelui ban Teodosie Corbeanu. Foto 1967; b - Lespedea funerară a marelui ban Teodosie Corbeanu, Desen 1967.

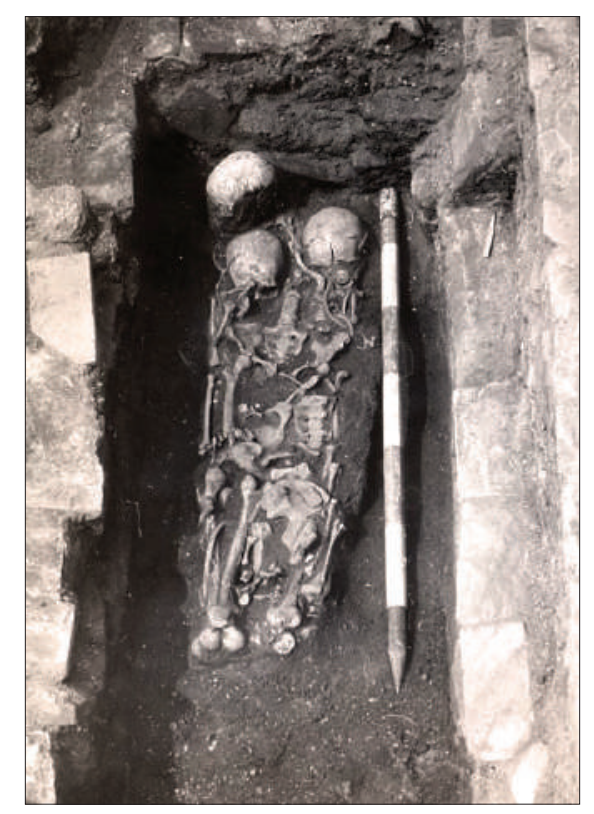

Figura 12. Mormântul marelui ban Teodosie Corbeanu cu cei doi „coconi” Gheorghe și Teodosie. Cavoul nr. 6. 1988. 

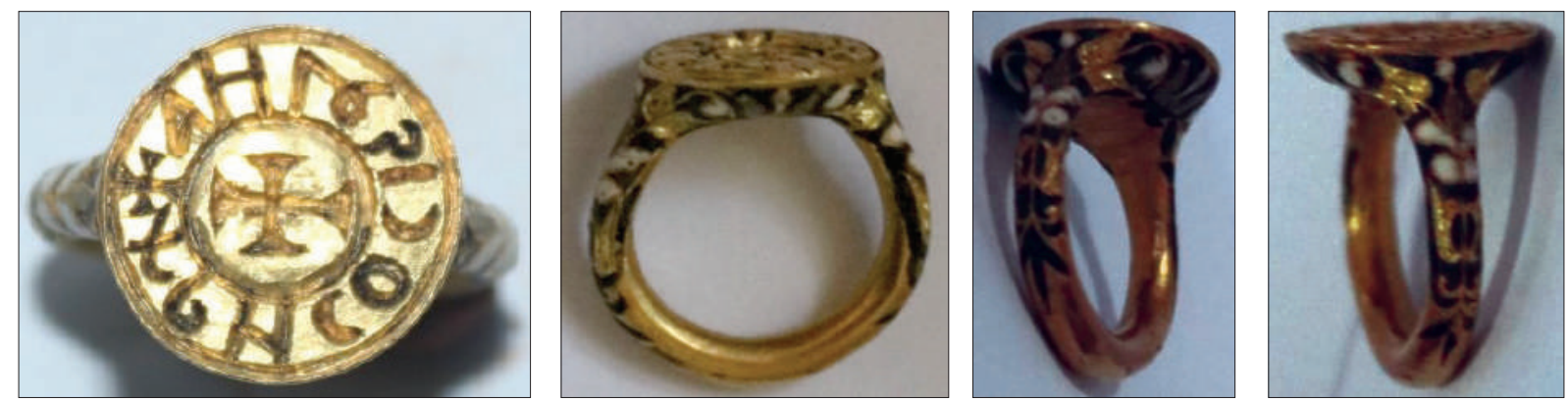

Figura 13 - Inel de aur cu inscripția Hrisosculina: a) șatonul sigiliu, b) profil longitudinal, c-d) profile transversale (Muzeul Civilizaţiei Gumelniţa din Olteniţa).
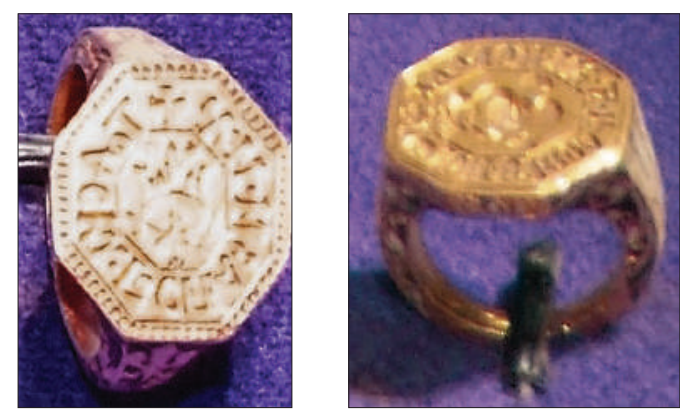

Figura 14. a-b - Inel-sigilar al Doamnei Tudosca (+1639), soția lui Vasile Lupu.
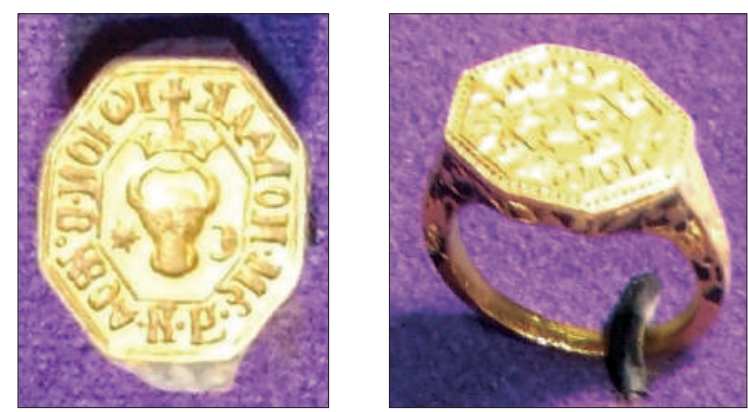

Figura 15. a-b - Inel-sigilar al lui Ioan Vodă, fiul lui Vasile Lupu.

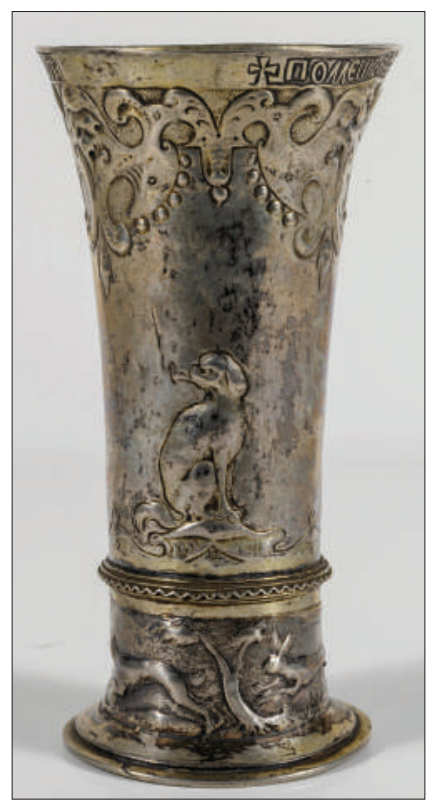

Figura 16. Potir din argint aurit de la Mănăstirea Dintr-un lemn cu inscripție de pomenire a lui Theodosie și jupaniței Hrisosculina (Muzeul Național de Artă al României). 
plate, cu un orificiu în centru. Atât petalele cât și discurile au marginile torsionate. În vârful petalelor se află o sferă, iar în al discurilor trei sfere așezate în triunghi. În centrul steluței o piatră semiprețioasă (turcoază) este prinsă prin patru gheare (nr. inv. 11.317 - 11.333) (Fig. 19).

Steluțele, filigranate, sunt prevăzute în spate cu mici orificii, care indică că ele au fost inițial cusute pe veșminte. Ulterior li s-a adăugat tulpina și au devenit ace de păr și de maramă. Redăm descrierea lor așa cum figurează în registrele de inventar ale MNIR:

11.317 (AR 858) - ac de văl, cu capul în formă de floare, cu 6 petale ascuțite, bordate cu un fir de metal răsucit, 3 emailate în interior cu albastru, cu o bobiță de metal în vârf, 3 cu firul răsucit dispus în formă de cerc, iar vârful petalei completat cu 3 bobițe în piramidă, iar mijlocul perforat; mijlocul florii marcat cu un cerc din fir de metal răsucit, din care se înalță o casetă cu 2 gheare, celelalte lipsă, în care este fixată o turcoază de formă neregulată; pe spate este fixat un ac, aplatizat pe porțiunea care este sudată; puțin îndoit și rupt, resudat, din care se păstrează o porțiune aproximativ de lungimea unei petale și separat încă o porțiune cam de lungimea florii; piatra ciobită are porțiuni lipsă; materialul zgâriat, lovit; cu material străin; emailul plesnit, corodat, puțin căzut; metalul oxidat. L cu codiță = 22,6 mm; L frg. Codiță = 14,7 mm; G=2,05 gr; (acul rupt la încercarea metalului). Ag 800\%o cf. Buletin de analiză BNRS 11819/1981 (G-2,02g).

11.318 (AR859) - numai floarea de la un ac de văl are 6 petale ascuțite, bordate cu un fir de metal răsucit, 3 emailate în interior cu albastru, cu o bobiță de metal în vârf, 3 cu firul răsucit dispus în formă de cerc, iar vârful petalei completat cu 3 bobițe în piramidă (la una din ele bobițele sunt turtite, aplatizate, deformate) cu mijlocul perforat; mijlocul florii marcat cu un cerc din fir de metal răsucit, din care se înalță o casetă cu 4 gheare, în care este fixată o turcoază de formă neregulată; pe spate se păstrează numai porțiunea aplatizată a acului sudată pe spatele piesei; acul fisurat înspre partea superioară; piatra ciobită, emailul corodat, metalul corodat, lovit, zgâriat, cu material străin. L = 18 mm G =1,95 gr. Ag 800\%o cf. Buletin de analiză BNRS 11819/1981 (G-1,91g).

11.319 (AR 860) - numai floarea de la un ac de văl are 6 petale ascuțite, bordate cu un fir de metal răsucit, 3 emailate în interior cu albastru, cu o bobiță de metal în vârf, 3 cu firul răsucit dispus în formă de cerc, iar vârful petalei completat cu 3 bobițe în piramidă; au mijlocul perforat (la una din petale, perforația astupată); mijlocul florii marcat cu un cerc din fir de metal răsucit, din care se înalță o casetă (numai baza se păstrează) pe care este lipită o turcoază de formă neregulată; ghearele se susținere a pietrei lipsă; pe spate se păstrează numai porțiunea aplatizată a acului sudat pe spatele piesei; piatra ciobită, emailul corodat, cu material străin. L=13/13,7/13,5 mm, G =2,27 gr. Ag 800\%o cf. Buletin de analiză BNRS 11819/1981. (G-2,25 g)

11.320 (AR 861) - numai floarea de la un ac de văl are 6 petale ascuțite, bordate cu un fir de metal răsucit, 3 emailate în interior cu albastru, cu o bobiță de metal în vârf, 3 cu firul răsucit dispus în formă de cerc, iar vârful petalei completat cu 3 bobițe în piramidă; au mijlocul perforat; mijlocul florii marcat cu un cerc din fir de metal răsucit, în care se păstrează urmele unei casete; pe spate se păstrează numai porţiunea aplatizată a acului sudat pe spatele piesei; acul resudat în partea inferioară; se mai păstrează încă o porţiune de ac separat, nesudat; metalul zgâriat, lovit; emailul corodat; cu material străin. L = 18 mm; L frg. Codiță = 8,7 mm; G = 1,87 gr. Ag 800\%o cf. Bul. de analiză BNRS 11819/1981 (G=1,83 g).

11.321 (AR 862) - ac de văl cu capul în formă de floare cu 6 petale ascuțite, bordate cu un fir de metal răsucit, 3 emailate în interior cu albastru, cu o bobiță de metal în vârf, 3 cu firul răsucit dispus în formă de cerc, iar vârful petalei completat cu 3 bobițe în piramidă cu mijlocul perforat; mijlocul florii marcat cu un cerc din fir de metal răsucit, din care se înalță o casetă cu 4 gheare, în care este fixată o turcoază de formă neregulată; pe spate este fixat un ac aplatizat pe porțiunea care este sudată, are vârful ascuțit; metalul corodat, piatra plesnită; cu urme de material străin. L = 66,6 mm; G = 2,64 gr. Ag 800\%o cf. Bul. de analiză BNRS 11819/1981 (G=2,60 g).

11.322 (AR 863) - ac de văl cu capul în formă de floare cu 6 petale ascuțite, bordate cu un fir de metal răsucit, 3 emailate în interior cu albastru, cu o bobiță de metal în vârf, 3 cu firul răsucit dispus în formă de cerc, iar vârful petalei completat cu 3 bobițe în piramidă cu mijlocul perforat; mijlocul florii marcat cu un cerc din fir de metal răsucit, din care se înalță o casetă cu 4 gheare, în care este fixată o turcoază de formă neregulată; pe spate este fixat un ac aplatizat pe porțiunea care este sudată; puțin plesnit, se mai păstrează separat, nesudat, încă un fragment din ac; piatra puțin ciobită și plesnită; emailul puternic corodat; metalul corodat, cu urme de material străin. $\mathrm{L}=45,8$ mm; L frg. Codiță = 23,3 mm; G = 2,97 gr. Ag 800\%o cf. Bul. de analiză BNRS 11819/1981 (G=2,91 g).

11.323 (AR 864) - ac de văl cu capul în formă de floare cu 6 petale ascuțite, bordate cu un fir de metal răsucit, 3 emailate în interior (în prezent sunt numai urme de material ?), cu o bobiță de metal în vârf, 3 cu firul răsucit dispus în formă de cerc, iar vârful petalei completat cu 3 bobițe în piramidă cu mijlocul perforat; mijlocul florii marcat cu un cerc din fir de metal răsucit, din care se înalță o casetă cu 4 gheare, în care este fixată o turcoază de formă neregulată; pe spate este fixat un ac aplatizat pe porțiunea care este sudată; are vârful ascuțit, piatra zgâriată; 

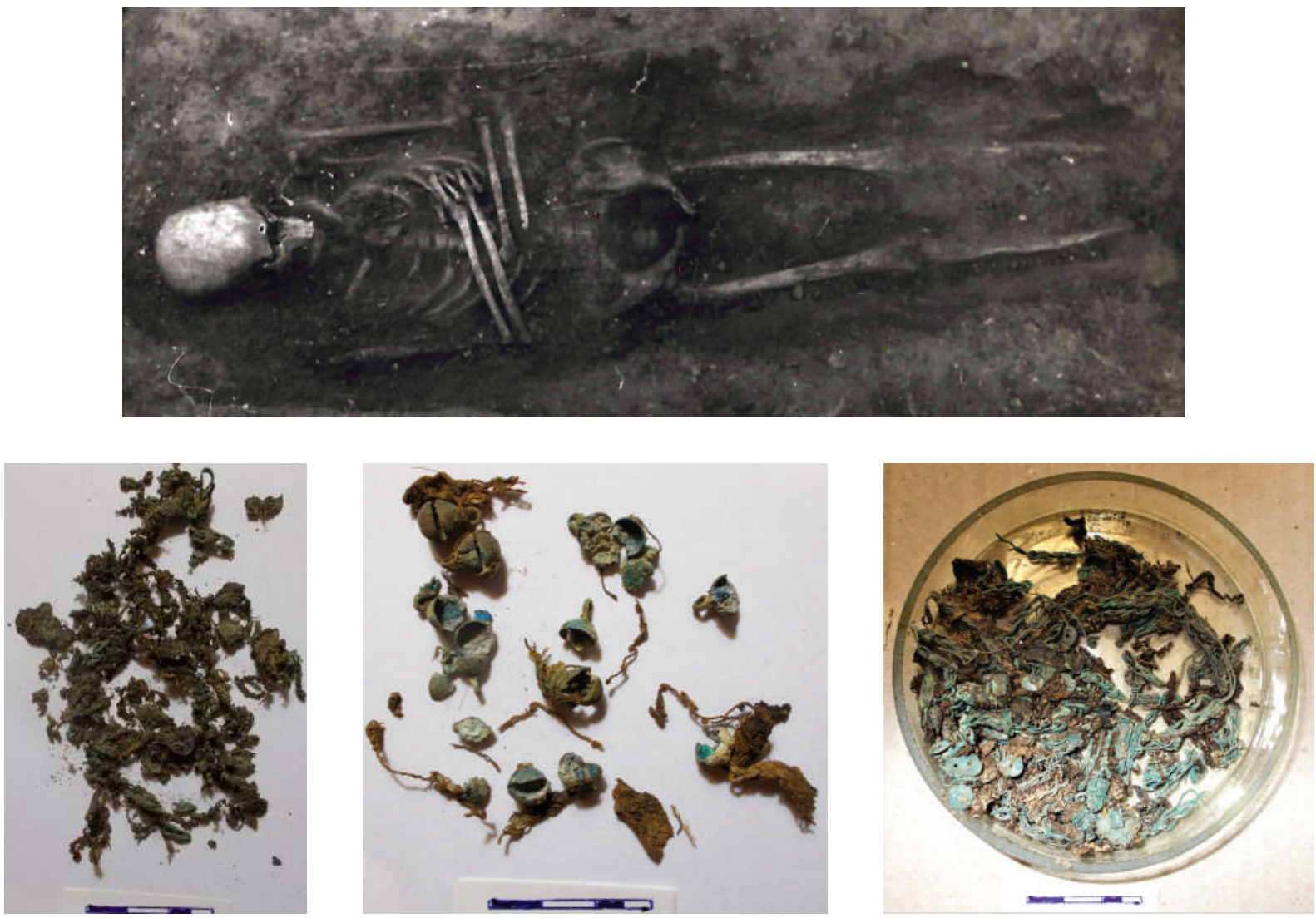

Figura 17. a - Mormântul nr. 2 din interiorul bisericii. 1965; b - fragmente de stofă cu bumbi de bronz din Mormântul 2 din Biserică; c - șnur cu paiete din Mormântul 41; d - șnur cu paiete din Mormântul 42.

emailul lipsă, acul deformat, pe piesă urme de material străin. L =65,4 mm; G =2,44 g. Ag 800\% cf. Bul. de analiză BNRS 11819/1981 ( $\mathrm{G}=2,39 \mathrm{~g})$.

11.324 (AR 865) - ac de văl cu capul în formă de floare cu 6 petale ascuțite, bordate cu un fir de metal răsucit, 3 emailate în interior cu albastru, cu o bobiță de metal în vârf, 3 cu firul răsucit dispus în formă de cerc, iar vârful petalei completat cu 3 bobițe în piramidă cu mijlocul perforat; mijlocul florii marcat cu un cerc din fir de metal răsucit, din care se înalță o casetă cu 4 gheare, în care este fixată o turcoază de formă neregulată; pe spate este fixat un ac aplatizat pe porțiunea care este sudată; partea inferioară a acului lipsă; materialul corodat; emailul corodat cu porțiuni lipsă; pe piesă urme de material străin. $\mathrm{L}=44,3 \mathrm{~mm} ; \mathrm{G}=2,91 \mathrm{~g}$. Ag $800 \%$ cf. Bul. de analiză BNRS $11819 / 1981(\mathrm{G}=2,85 \mathrm{~g})$.

11.325 - ac de văl cu capul în formă de floare cu 6 petale ascuțite, bordate cu un fir de metal răsucit, cu o bobiță de metal în vârf, 3 cu firul răsucit dispus în formă de cerc, iar vârful petalei completat cu 3 bobițe în piramidă cu mijlocul perforat; mijlocul florii marcat cu un cerc din fir de metal răsucit; pe spate este fixată o mică porțiune dintr-un ac; materialul corodat; emailul corodat cu porțiuni lipsă; pe piesă urme de material străin. Separat s-a păstrat piatra turcoază de formă neregulată. L cca 14 mm.

11.326 (AR 867) - ac de văl cu capul în formă de floare cu 6 petale ascuțite, bordate cu un fir de metal răsucit, 3 emailate în interior cu albastru, cu o bobiță de metal în vârf, 3 cu firul răsucit dispus în formă de cerc, iar vârful petalei completat cu 3 bobițe în piramidă cu mijlocul perforat; mijlocul florii marcat cu un cerc din fir de metal răsucit, din care se înalță o casetă cu 4 gheare, în care este fixată o turcoază de formă neregulată; pe spate este fixat un ac aplatizat pe porțiunea care este sudată; are vârful ascuțit; din email nu se mai păstrează decât f. ușoare urme; metalul cu urme de material străin, piatra ușor ciobită. L = 64,5 mm; G =2,48 g. Ag $800 \%$ off. Bul. de analiză BNRS 11819/1981 $(\mathrm{G}=2,44 \mathrm{~g})$.

11.327 (AR 868) - ac de văl cu capul în formă de floare cu 6 petale ascuțite, bordate cu un fir de metal răsucit, 3 emailate în interior cu albastru, cu o bobiță de metal în vârf, 3 cu firul răsucit dispus în formă de cerc, iar vârful petalei completat cu 3 bobițe în piramidă cu mijlocul perforat; mijlocul florii marcat cu un cerc din fir de metal răsucit, din care se înalță o casetă cu 4 gheare, în care este fixată o turcoază de formă neregulată; pe spate este fixat 

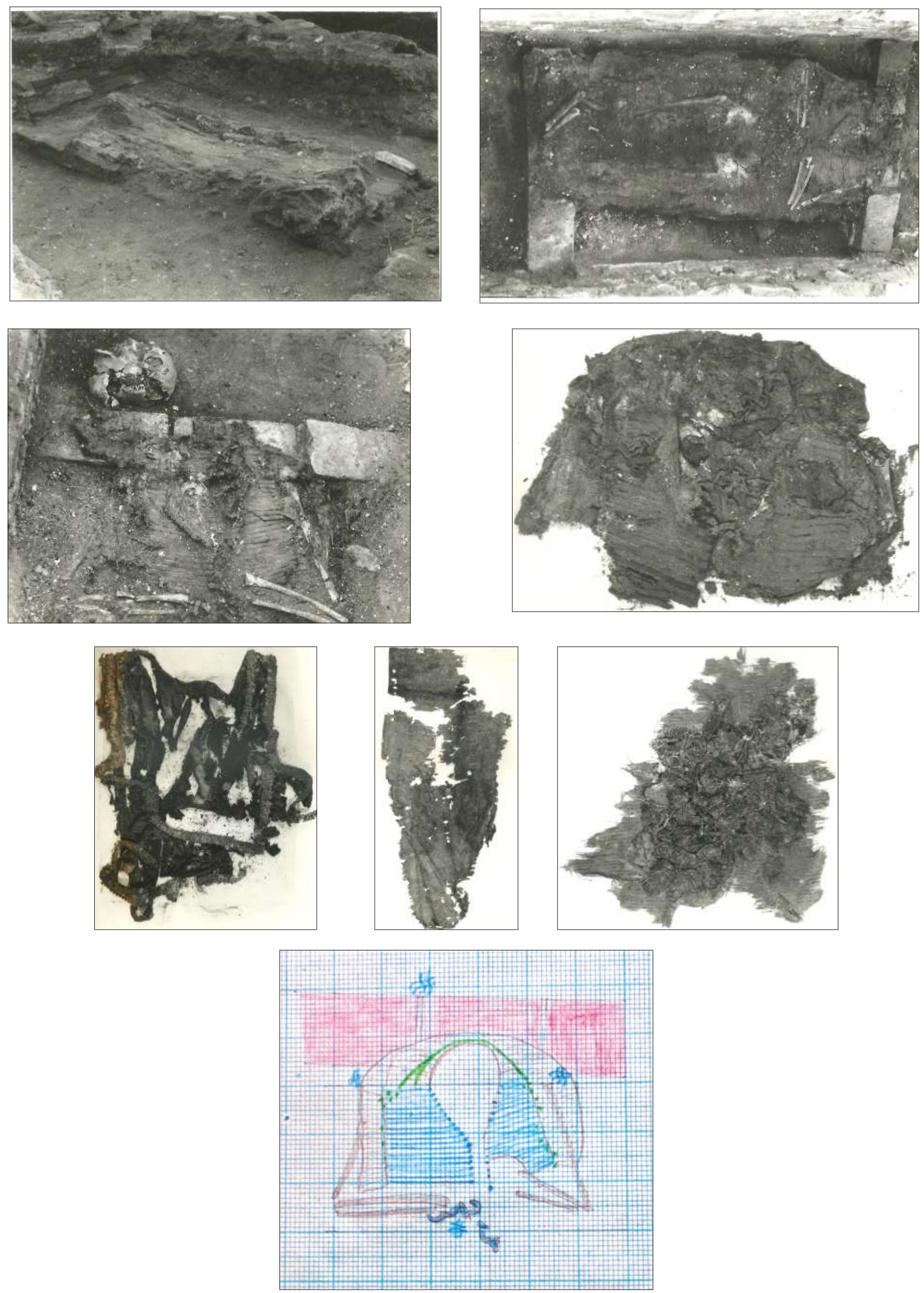

Figura 18. a-j - Cavoul nr. 4: a - înaintea deschiderii; b - conținutul; c - jumătatea superioară a corpului persoanei înhumate în cavou; $\mathrm{d}$ - corsajul conteșului; e - corsajul rochiei; g-i - fragmente din conteș; $\mathrm{j}$ - desen arheologic cu descoperiri din interiorul cavoului. 


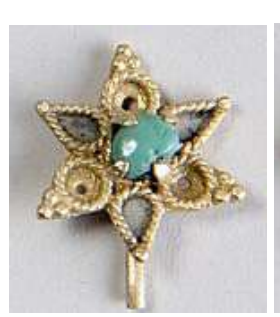

11.317

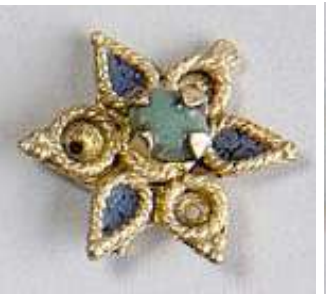

11.318

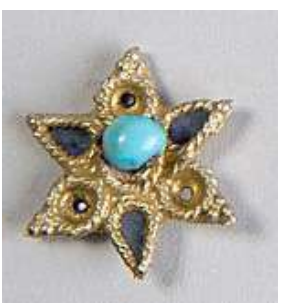

11.319

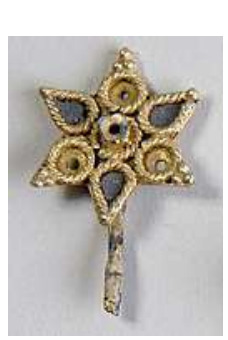

11.320
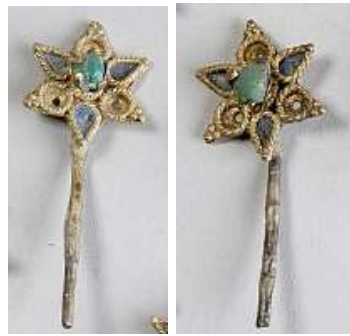

11.321

11.322

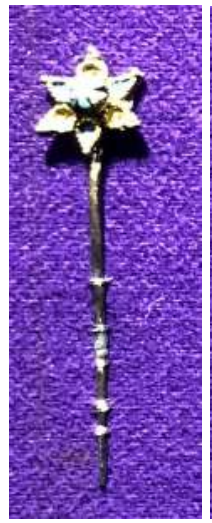

11.323

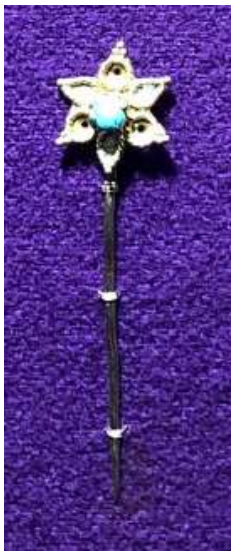

11.327

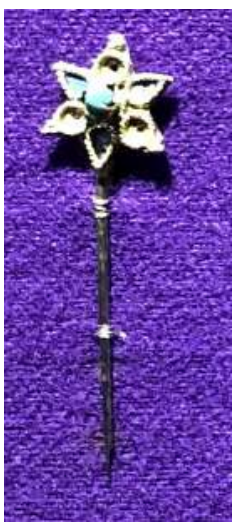

11.324

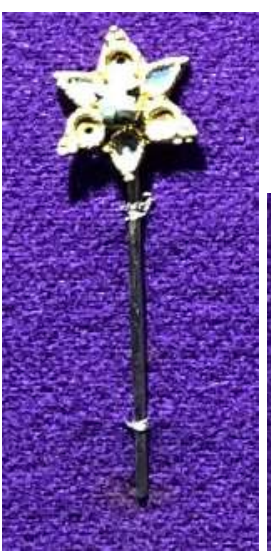

11.328

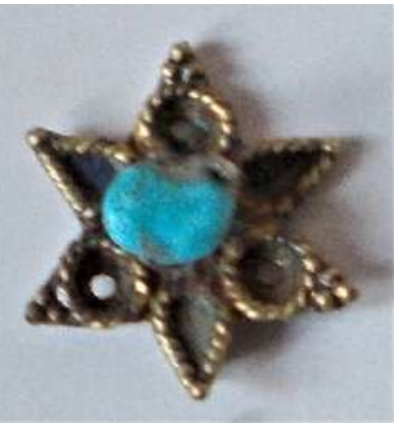

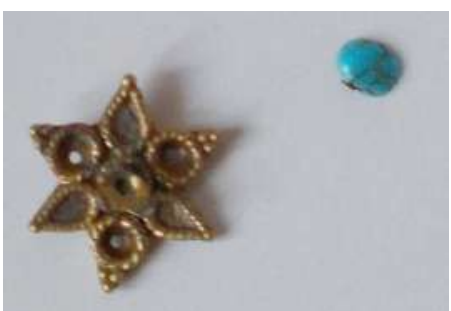

11.325 fața

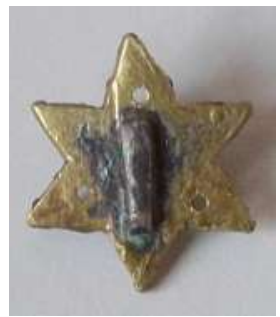

11.325 spate

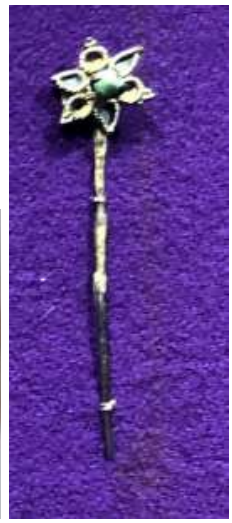

11.326

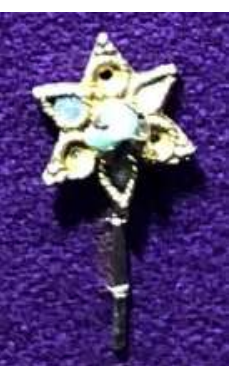

11.329

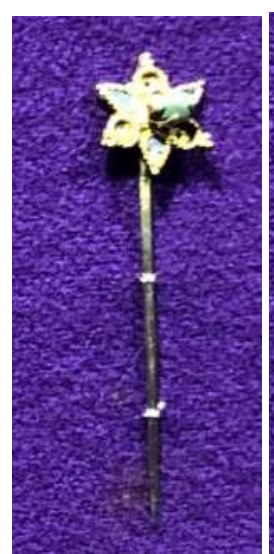

11.330

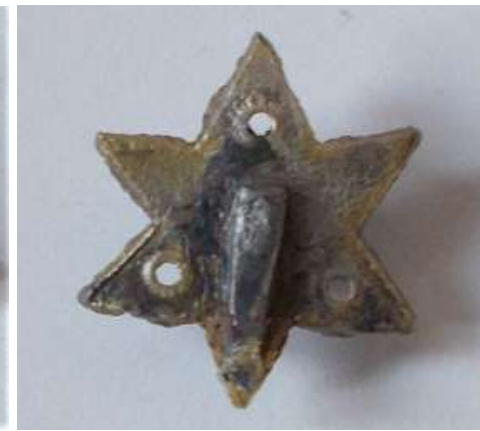

11.332

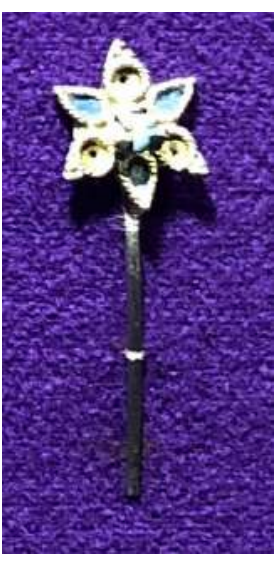

11.331

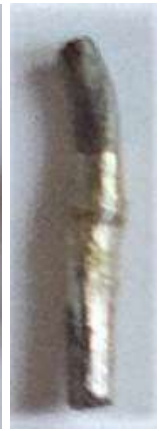

11.333

Figura 19. Ace de maramă din cavoul nr. 4. 
un ac aplatizat pe porțiunea care este sudată; se mai păstrează separat, nesudat, încă un fragment din ac (partea inferioară); piatra puțin ciobită, emailul corodat, metalul corodat; urme de material străin. L =20,6 mm; L frg. Codiță = 41,7 mm; G = 2,55 gr. Ag 800\%o cf. Bul. de analiză BNRS 11819/1981 (G=2,53 g).

11.328 (AR 869) - ac de văl cu capul în formă de floare cu 6 petale ascuțite, bordate cu un fir de metal răsucit, 3 emailate în interior cu albastru, cu o bobiță de metal în vârf, 3 cu firul răsucit dispus în formă de cerc, iar vârful petalei completat cu 3 bobițe în piramidă cu mijlocul perforat; mijlocul florii marcat cu un cerc din fir de metal răsucit, din care se înalță o casetă cu 3 gheare, în care este fixată o turcoază de formă neregulată; pe spate este fixat un ac aplatizat pe porțiunea care este sudată; se mai păstrează separat, nesudat, încă un fragment din ac; piatra puțin plesnită şi ciobită, emailul corodat; se mai păstrează uşoare urme în 2 petale, metalul corodat are urme de material străin. L =30,2 mm; L frg. Codiţă = 13 mm; G =2,33 gr. Ag 800\%o cf. Bul. de analiză BNRS 11820/1981 $(\mathrm{G}=2,30 \mathrm{~g})$.

11.329 (AR 870) - ac de văl cu capul în formă de floare cu 6 petale ascuțite, bordate cu un fir de metal răsucit, 3 emailate în interior cu albastru, cu o bobiță de metal în vârf, 3 cu firul răsucit dispus în formă de cerc, iar vârful petalei completat cu 3 bobițe în piramidă cu mijlocul perforat; mijlocul florii marcat cu un cerc din fir de metal răsucit, din care se înalță o casetă cu 4 gheare, în care este fixată o turcoază de formă neregulată; pe spate este fixat un ac aplatizat pe porțiunea care este sudată; se mai păstrează separat, nesudat, încă 4 fragmente din ac; emailul puternic corodat, nu se mai cunoaște aproape deloc; metalul cu urme de material străin. L=18,4 mm; L frg. Codiță = 33,3 mm; frg. 2 codiță = 15,4 mm; frg. 3 codiță = 10,5 mm; frg. 4 codiță =6,7 mm; G=3,06 g. Ag 800\%o cf. Bul. de analiză BNRS 11820/1981 (G=3,05 g).

11.330 (AR 871) - ac de văl cu capul în formă de floare cu 6 petale ascuțite, bordate cu un fir de metal răsucit, 3 emailate în interior cu albastru, cu o bobiță de metal în vârf, 3 cu firul răsucit dispus în formă de cerc, iar vârful petalei completat cu 3 bobițe în piramidă cu mijlocul perforat; mijlocul florii marcat cu un cerc din fir de metal răsucit, din care se înalță o casetă cu 4 gheare, în care este fixată o turcoază de formă neregulată; pe spate este fixat un ac aplatizat pe porțiunea care este sudată; acul are vârful rupt; metalul corodat cu urme de material străin; emailul puternic corodat, vizibil la o singură petală. L =57,3 mm; G=3,10 g. Ag 800\%o cf. Bul. de analiză BNRS $11820 / 1981(\mathrm{G}=3,06 \mathrm{~g})$.

11.331 (AR 872) - ac de văl cu capul în formă de floare cu 6 petale ascuțite, bordate cu un fir de metal răsucit, 3 emailate în interior cu albastru, cu o bobiță de metal în vârf, 3 cu firul răsucit dispus în formă de cerc, iar vârful petalei completat cu 3 bobițe în piramidă cu mijlocul perforat; mijlocul florii marcat cu un cerc din fir de metal răsucit, din care se înalță o casetă cu 4 gheare, în care este fixată o turcoază de formă neregulată; pe spate este fixat un ac aplatizat pe porțiunea care este sudată; din ac se păstrează numai o porțiune la partea superioară; piatra ciobită, plesnită; ghearele deformate, rupte; emailul puternic cordat; se păstrează ușoare urme; metalul corodat cu urme de material străin. $L=35,2$ mm; G = 2,75 g. Ag 800\%o cf. Bul. de analiză BNRS 11820/1981 (G=2,72 g).

11.332 (AR 873) - ac de văl cu capul în formă de floare cu 6 petale ascuțite, bordate cu un fir de metal răsucit, 3 emailate în interior cu albastru, cu o bobiță de metal în vârf, 3 cu firul răsucit dispus în formă de cerc, iar vârful petalei completat cu 3 bobițe în piramidă cu mijlocul perforat; mijlocul florii marcat cu un cerc din fir de metal răsucit, din care se înalță o casetă cu 4 gheare, în care este fixată o turcoază de formă neregulată; pe spate este fixat un ac aplatizat pe porțiunea care este sudată; din ac se păstrează doar o mică porțiune la partea superioară, emailul nu se mai zărește; piatra ciobită, plesnită; metalul cu urme de material străin. L =20, 8 mm; G =2,10 g. Ag 800\%o cf. Bul. de analiză BNRS 11820/1981 (G=2,06 g).

11.333 - ac de văl cu capul în formă de floare cu 6 petale ascuțite, bordate cu un fir de metal răsucit, 3 emailate în interior cu albastru, cu o bobiță de metal în vârf, 3 cu firul răsucit dispus în formă de cerc, iar vârful petalei completat cu 3 bobițe în piramidă cu mijlocul perforat; mijlocul florii marcat cu un cerc din fir de metal răsucit, din care se înalță o casetă cu 2 gheare, în care este fixată o turcoază de formă neregulată; pe spate este fixată o mică porțiune dintr-un ac aplatizat; emailul nu se mai zărește; metalul cu urme de material străin. L cca 15 mm.

Tehnica filigranului de pe steluțe este atestată în sec. XVI și XVII în Transilvania pe pahare și alte vase de aur sau argint, folosite în bisericile catolice sau evanghelice. Astfel de vase se află în muzeul Bruckenthal din Sibiu și în colecția Episcopiei Catolice din Alba Iulia și aparțin artei Renașterii ${ }^{10}$.

În dreptul celor două urechi s-a descoperit câte un cercel de aur (750 o/oo Au; 7,20 - 7,45 g. Lungimea totală $=46$ mm; lățimea maximă = 25 mm). Lucrați prin turnare, ciocănire și treflare, apoi emailare. Se compun dintr-o buclă inelară, tăiată, cu un diametru total de 1,4 cm. De această buclă, prin trei verigi întrepătrunse, atârnă corpul propriu-

$\overline{10}$ Informații Corina Nicolescu, 1968. 
zis al cercelului compus din două grupe simetrice de câte trei vrejuri (una în dreapta, cealaltă în stânga) emailate cu verde. În centru, pe un motiv vegetal (4 frunze perpendiculare între ele) este prinsă o casetă paralelipipedică în care este incastrată o piatră roșie. În partea inferioară a corpului, prin trei verigi întrepătrunse, atârnă trei pandantive în formă de caliciu floral cu 4 sepale. Atât laturile casetei cât și sepalele pandantivelor sunt decorate cu volute gemene (inv. nr. 11.311-11.312) (Fig. 20).

Cercel, Căscioarele - nr. inv. 11.311 - Au. 725/1638 compus dintr-o placă de aur suspendată pe un inel deschis prin intermediul unei verigi micuțe; placa traforată şi cizelată sub forma de volute dispuse simetric şi decorate în partea superioară cu șase granule mici de aur; în centru sunt sudate patru frunzulițe mici curbate, dispuse în cruce, între care a fost așezat un șaton tronconic cu baza dreptunghiulară cu o piatră roșie. În partea inferioară a plăcii sunt prinse trei pandantive mici în formă de tije. Pe faţă la baza unei volute s-a păstrat o porţiune de email verde; pe spate sunt urme de email roșu, verde și alb, complet cristalizat; veriga este deformată, cu capetele puternic depărtate; tijele pandantiv sunt drepte; piatra zgâriată; piesa este în unele porțiuni înnegrită. L=48 mm; L placă = 26,3 mm; G = 7,15 g. Au 900\%o (conform buletinului de analiză BNRSR 18030/1980) G = 7,22 g.

Cercel, Căscioarele - nr. inv. 11.312 - Au. 726/1638 compus dintr-o placă de aur suspendată pe un inel deschis prin intermediul unei verigi micuțe. Placa traforată şi cizelată sub formă de volute dispuse simetric şi decorate în partea superioară cu șase granule mici de aur. În centru sunt sudate patru frunzulițe mici curbate, dispuse în cruce, între care a fost aşezat un șaton tronconic cu baza dreptunghiulară cu o piatră roșie; în partea inferioară a plăcii sunt prinse trei pandantive mici în formă de tije. Pe faţă, pe două din volute s-a păstrat email verde; pe spate sunt urme de email roșu, verde şi alb, complet cristalizat; tijele pandantivului strâmbe; cele patru frunzulițe şi montura cu rubin se mișcă din nit; piatra este ușor ciobită. L=46 mm; L placă $=26$ mm; G=7,35 g. Au 500\%o; G=7,44 g.

Pe un deget al mâinii drepte a fost descoperit un inel de aur (750 o/oo Au; 8,49 g; Înălţime = 2,6 cm.) alcătuit dintr-o verigă decorată la capete cu motive vegetale în vrej emailate cu verde şi roșu. Şatonul se compune dintr-o casetă paralelipipedică în care este încastrat un safir. Laturile acestei casete sunt decorate cu volute gemene din email verde și roșu, cloisonné (inv. nr. 11.313) (Fig. 21).

Inel cu peruzea, Căscioarele - nr. inv. 11.313 - Au. 727/1638; G = 8,49 g. Veriga are pe jumătate din perimetru, de o parte și de alta a șatonului, volute cu urme de email verde, roșu, alb. Şatonul are forma unui trunchi de piramidă cu baza dreptunghiulară, așezat pe un postament; a avut suprafața bordurii emailată; în şaton o piatră albastru deschis. Veriga deformată; piatra prezintă zgârieturi și pori; pe piesă urme de lovire și zgâriere, precum şi urme de material străin; din emailare nu se păstrează decât uşoare urme. L max = 26 mm; Ø verigă $=11,8 / 13,4$ mm; G = 8,40 g. Au 900\%o (conform buletinului de analiză BNRSR 18030/1980). G=8,47 g.

În ceea ce privește tehnica de execuţie și de decorare a inelului și cerceilor descoperiți în cavoul nr. 4 se observă numeroase similitudini cu cercelul Doamnei Elina, soția lui Matei Basarab, înmormântată la 15 august 1653 în Biserica Domnească din Târgoviște ${ }^{11}$ (Fig. 22). De aceea atribuim aceste podoabe unui singur atelier din prima jumătate a sec. al XVII-lea, atelier ce aparține artei de la sfârşitul Renașterii și începutul Barocului, aflat în Transilvania. Nu ar fi exclus ca acest atelier să fi executat și acele de păr, care, pe baza caracteristicilor lor, sunt lucrate și ele într-un singur atelier.

Printre alte piese descoperite în mormânt menționăm o copcă, paiete, o perlă mică și unele fire de argint și de aur, împletite, ce provin din maramă și din celelalte veșminte.

În timpul dezvelirii mormântului s-au putut observa, in situ, conteșul, rochia și cămașa, care, alături de maramă, constituiau piesele de îmbrăcăminte ce compuneau vestimentaţia celei înmormântate (Fig. 18 b-j).

Din cămașă nu s-a putut remarca decât gulerul.

Conteșul, purtat atât de bărbați cât și de femei, începând cu a doua jumătate a secolului al XVI-lea ${ }^{12}$, este răscroit pe lângă gât. În față se închide cu nasturi, din împletitură de fir, ce corespund cu 18-24 găitane, din galon de fir, dispuse pe cei doi piepți.

Sub conteș se afla rochia din țesătură de mătase alcătuită dintr-un corsaj răscroit, strâns pe talie, cu decolteul pătrat. În față se închidea cu nasturi ce nu s-au păstrat însă. Fusta era încrețită la spate și pe piept. În jurul răscroielii de la gât și umeri sunt aplicate 1-3 rânduri de galon de fir, formând o ornamentație bogată.

Conteșul și rochia își găsesc cele mai bune analogii în costumele de la mijlocul secolului al XVII-lea cum ar fi cele descoperite la Voroneț (Fig. 23 a) sau în naosul bisericii mănăstirii Dragomirna ${ }^{13}$ (Fig. 23 b, d-g) ori cel din

\footnotetext{
11 Constantinescu, Moisescu, Nicolăescu-Plopșor 1967, 306, fig. 3.

12 Nicolescu 1970, 44.

${ }^{13}$ Nicolescu 1970, 44, fig. 19 pentru conteș și 46, fig. 20-22 pentru rochie.
} 

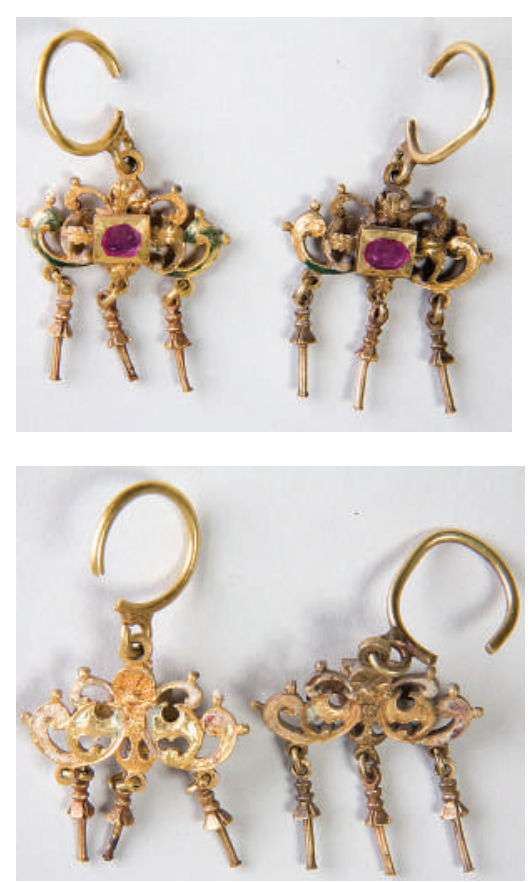

Figura 20. Cerceii 1 și 2 din cavoul nr. 4: a) față; b) spate; c) desen (Elena Becheș, 1968).
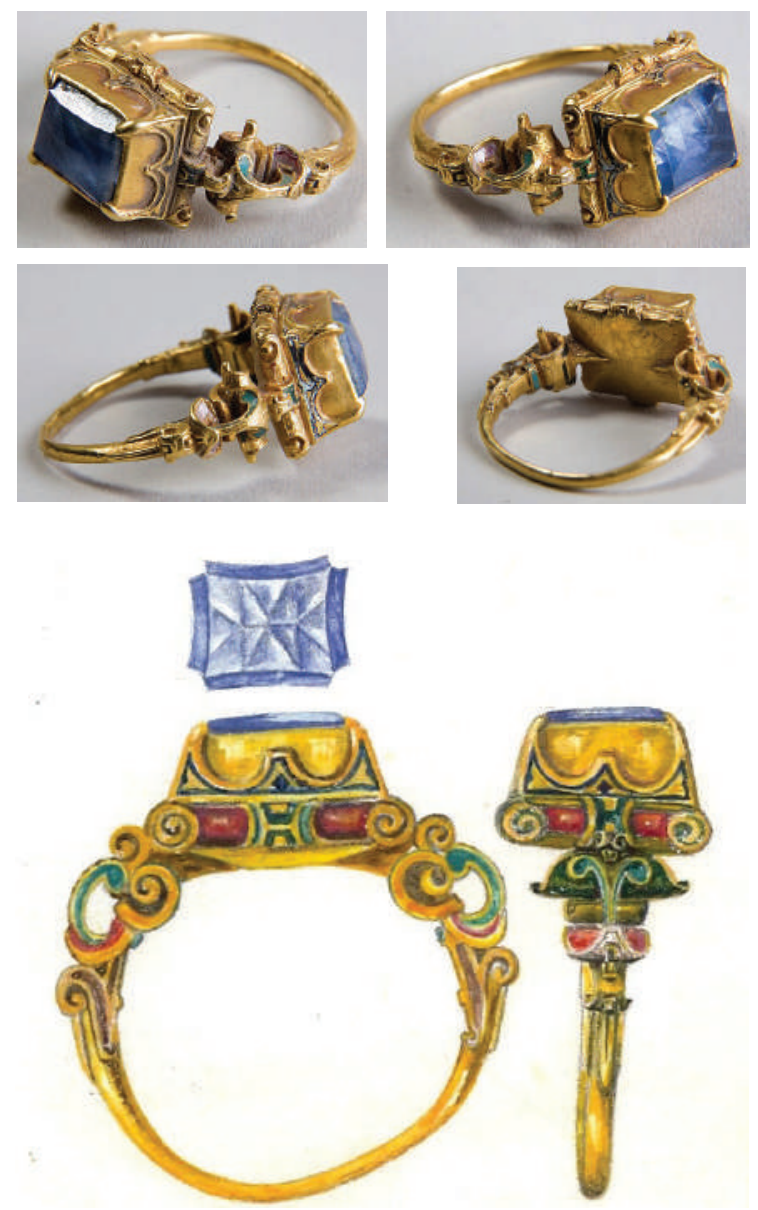

Figura 21. Inel de aur din cavoul nr. 4: a) profil oblic; b) profil oblic; c) profil; d) spate; e) desen (Elena Becheș, 1968).
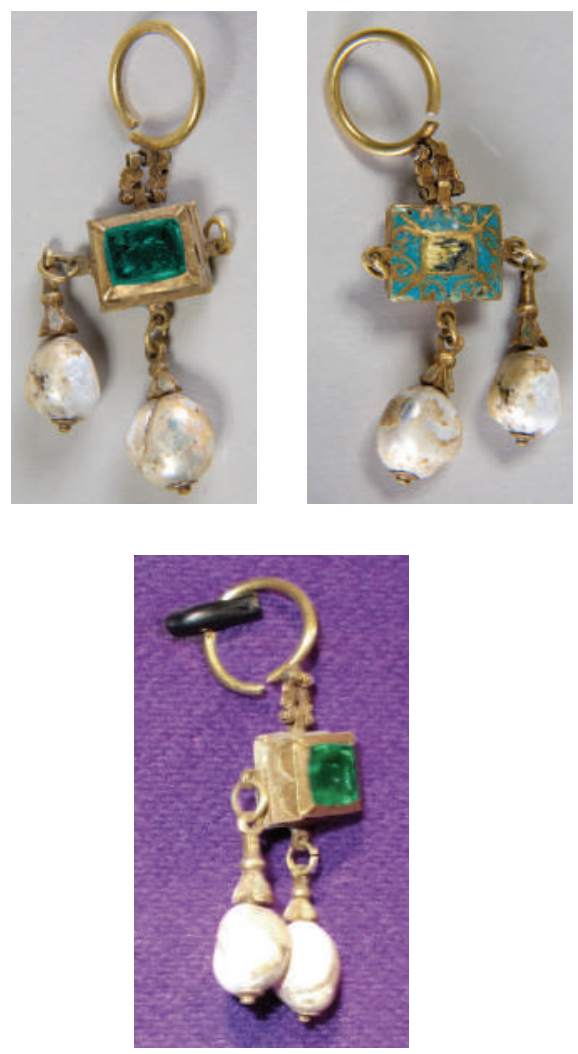

Figura 22. a-b Cercel al Doamnei Elina, Târgoviște. 

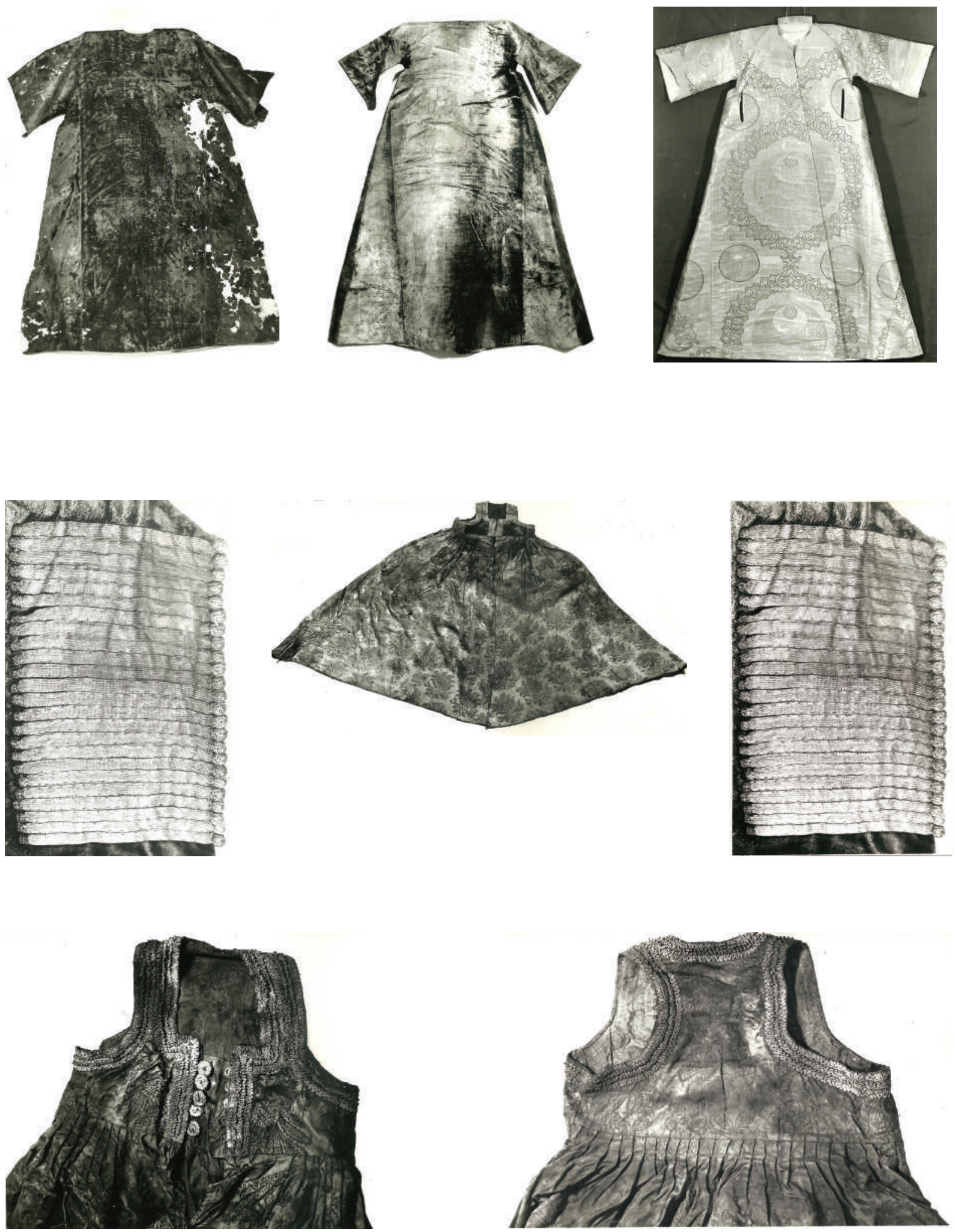

Figura 23. Asemănări de costume: a - conteș Voroneț; b - conteș Dragomirna; c - conteș din felon; d - găitane conteș Dragomirna; e - rochie Dragomirna; f - corsaj față rochie Dragomirna; g - corsaj spate rochie Dragomirna. 

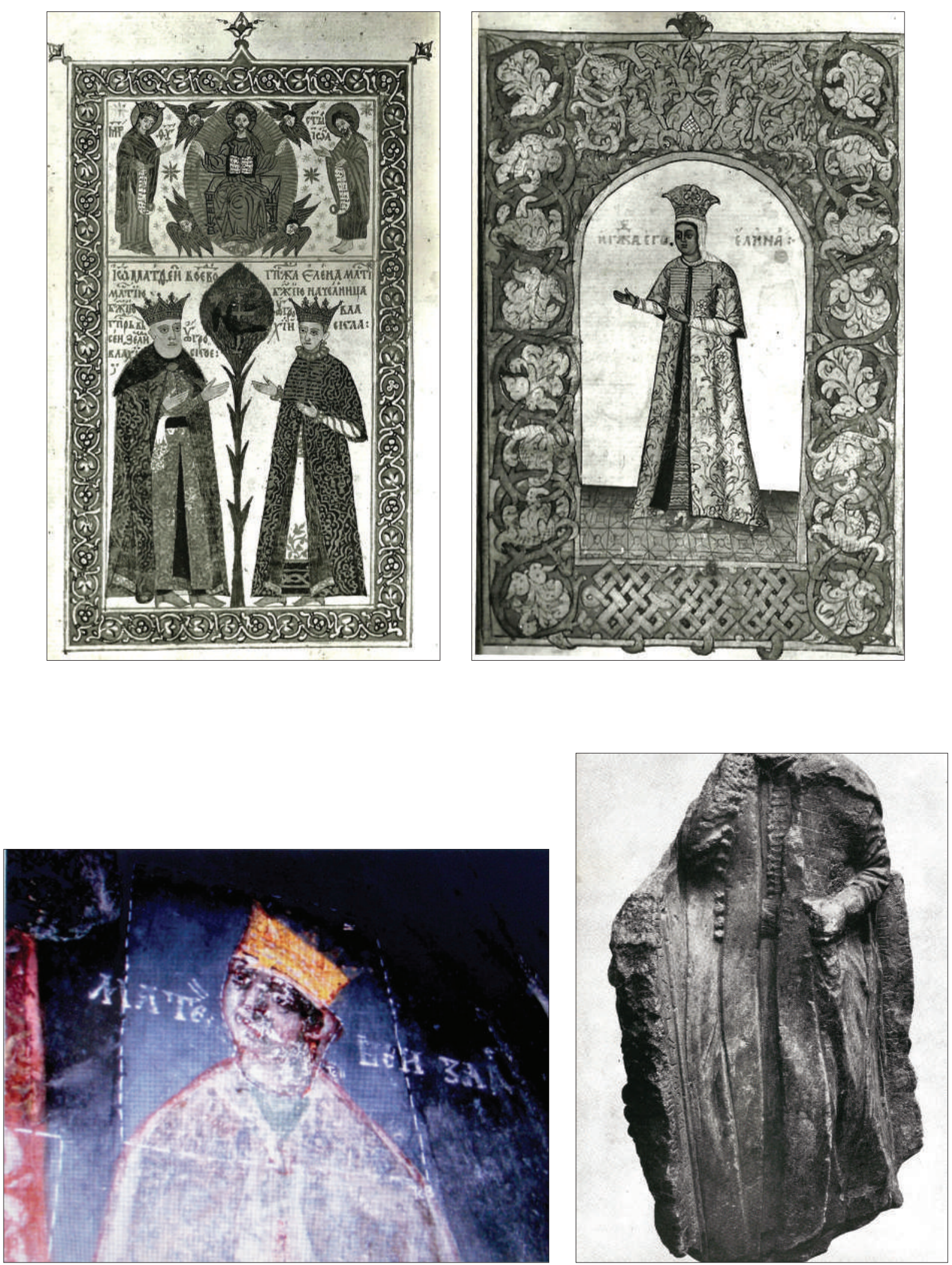

Figura 24. a-d - Persoane cu astfel de îmbrăcăminte: a1-2 - Matei Basarab și Doamna Elina, manuscrise de epocă; b - Doamna Elina; c - Mateiaș, Tabloul votiv din Biserica Mănăstirii Strehaia; d - piatra glisantă de pe mormântul lui Mateiaș. 
felon (Fig. 23 c) precum și cele purtate de Matei Basarab, de Doamna Elina ${ }^{14}$, decedată la 15 august 1653, soția lui Matei Basarab (1588 - 9 aprilie 1654) (Fig. 24 a-b) sau de Mateiaș în Tabloul votiv din Biserica Mănăstirii Strehaia (Fig. 24 c) ori pe piatra gisant de pe mormântul său de la Târgoviște, realizată de sculptorul Elias Nicolaie în $1652^{15}$ (Fig. 24 d).

După cum se vede, caracteristicile îmbrăcămintei și ale bijuteriilor ne îndreptățesc a socoti mormântul din cavoul nr. 4 ca aparţinând unei boieroaice de rang înalt. Prin faptul că cele mai mari asemănări, mergând uneori până la similitudini ce denotă apartenența obiectelor respective unui singur atelier, se întâlnesc la cercelul și veșmintele Doamnei Elina, ne-au îndemnat a presupune strânsa înrudire între persoana înmormântată aici, la Cătălui, și soția domnitorului Țării Românești.

Săpăturile efectuate în Biserica Domnească din Târgoviște ${ }^{16}$ au dus, printre altele, la identificarea mormintelor Doamnei Elina și a lui Mateiaș (mort în ziua de miercuri 16 iunie 1652 la ceasul 2 din noapte), fiul lui Udriște Năsturel (fratele Doamnei Elina) cu Maria Corbeanu (sora marelui ban Teodor Corbeanu și nepoata de fiu a marelui spătar Stan din Corbi cu jupânița Caplea), prima sa soție. Pentru cavoul nr. 1, în care se afla Mateiaș (Matei postelnicul, cum este numit în documente), demne de remarcat în cele de faţă - privind vestimentația - sunt piatra glisantă (sculptor Elias Nicolai), mantaua cu galoane și nasturi precum și giulgiul de mătase ${ }^{17}$.

Se știe însă că Maria Corbeanu-Năsturel moare în iarna lui 1635, la două săptămâni după naștere, iar fiul ei Mateiaş va fi înfiat de mătuşa sa, Doamna Elina precum și de Matei Basarab, care-l va boteza cu numele său. Prin urmare, între Maria Corbeanu-Năsturel și cumnata sa Doamna Elina erau strânse raporturi nu numai de rudenie dar, probabil, și de amiciție. De aceea, pe baza menționatelor similitudini dintre podoabele și îmbrăcămintea purtată de Doamna Elina și descoperirile din cavoul nr. 4 de la Cătălui, suntem de părere că mormântul descris în rândurile de față a aparținut Mariei Corbeanu, soția lui Udriște Năsturel. Înmormântarea ei la Cătălui, lângă mormintele bunicilor ei, ctitori ai respectivei biserici, s-ar explica prin faptul că biserica din Hereşti, unde era moșia și reședința familiei Năsturel, era în profunde transformări și rezidiri.

Săpăturile arheologice de la Herești, mai vechi și relativ mai noi, executate de soții Voica și Nicolae Puşcaşu (1959-1960), Ion Chicideanu (1977) și Adrian Bătrîna (1987), au dus la identificarea a patru biserici ridicate pe același loc. Primele două biserici erau de lemn și sunt datate la sfârșitul secolului XV (B1) și între mijlocul secolului XVI - sfârșitul secolului XVI.

Primei biserici îi aparțin mormintele M. 3 - M. 7 (pe atunci exterioare, azi în pronaos), jefuite însă în diferite etape şi ne mai conținând nimic. A treia biserică, fiind în același timp prima biserică din zid (B3a), a fost ridicată de marele logofăt Radu Năsturel, pe când era postelnic (1565-1641), și de soția sa Despina, din neamul lui Mihai Viteazul. Acestei biserici, la începutul secolului al XVII-lea (anterior cutremurului din 8 noiembrie 1620 cu magnitudinea de 7,5), i se adaugă spre vest un pridvor. Întreaga nouă construcție (B3b) este funcțională până spre anul 1644, an în care este sfințită a patra biserică (B4) de pe acest loc, a doua din zid și care s-a înălțat pe vechile temelii.

Pisania aflată deasupra ușii de la intrarea în pronaosul actual - scrisă în limba slavonă - redactată de însuși Udriște Năsturel, spune: ,în acest sfânt și dumnezeiesc locaş din însuși temelia lui a fost clădit și înălțat cu ajutorul lui Dumnezeu prin stăruirea și porunca luminăției sale cinstitoare Principesa (Cneaghina) Doamna Elina, cu harul lui Dumnezeu stăpână și voievodeasă a Țării Ungro-Vlahiei, soția preacinstitului și autocrat (domnitor) Io Matei Basarab, cu truda și ajutorul în parte a celor doi buni frați ai săi, Căzan Năsturel și Orest Năsturel, domnind atunci întru Dumnezeu creștinul domnitor, cel mai sus pomenit, soțul acesteia, pre timpul Arhiepiscopului Kir Teofil și episcopul de Râmnic Kir Ignatie și cel de Buzău Kir Ștefan în anul de la zidirea lumii 1644 și vătaf de lucrări a fost Mamant Barbulov din Netezești”"18.

Iar în partea de sud a pronaosului s-au înglobat mormintele M. 1 și M. 2, cu zidărie din cărămidă, destinate ctitorilor, datând din perioada anterioară (B3a) și fiind amenajate de Doamna Elina.

M. 1 este locul de veci al marelui logofăt Radu Năsturel (1565-1641), tatăl Doamnei Elina.

\footnotetext{
${ }^{14}$ Nicolescu 1970, 110, fig. 59 și 112, fig. 60.

${ }^{15}$ Constantinescu et al. 2008-2009, 113-117, fig. 62; Ilie 2010, 52, f. 2.

${ }^{16}$ Constantinescu, Moisescu, Nicolăescu-Plopșor 1967, 306, fig. 3; Constantinescu et al. 2008-2009, passim, 112, fig. 68 (pentru cercel). Mormântul Doamnei Elina se afla în ... cavoul nr. 4 (!!!).

17 Constantinescu et al. 2008-2009, 108-109, fig. 61-63.

${ }_{18}$ Text preluat de pe https://audiotravelguide.ro/biserica-sf-voievozi-heresti, text mai apropiat de originalul în slavonă al pisaniei publicată de N. Iorga - Inscripții din bisericile României. Adunate, adnotate și publicate, I, București, 1905, p. 9091, dar care dă o traducere aproximativă. Însă și acest text folosește neologisme inadecvate ...
} 

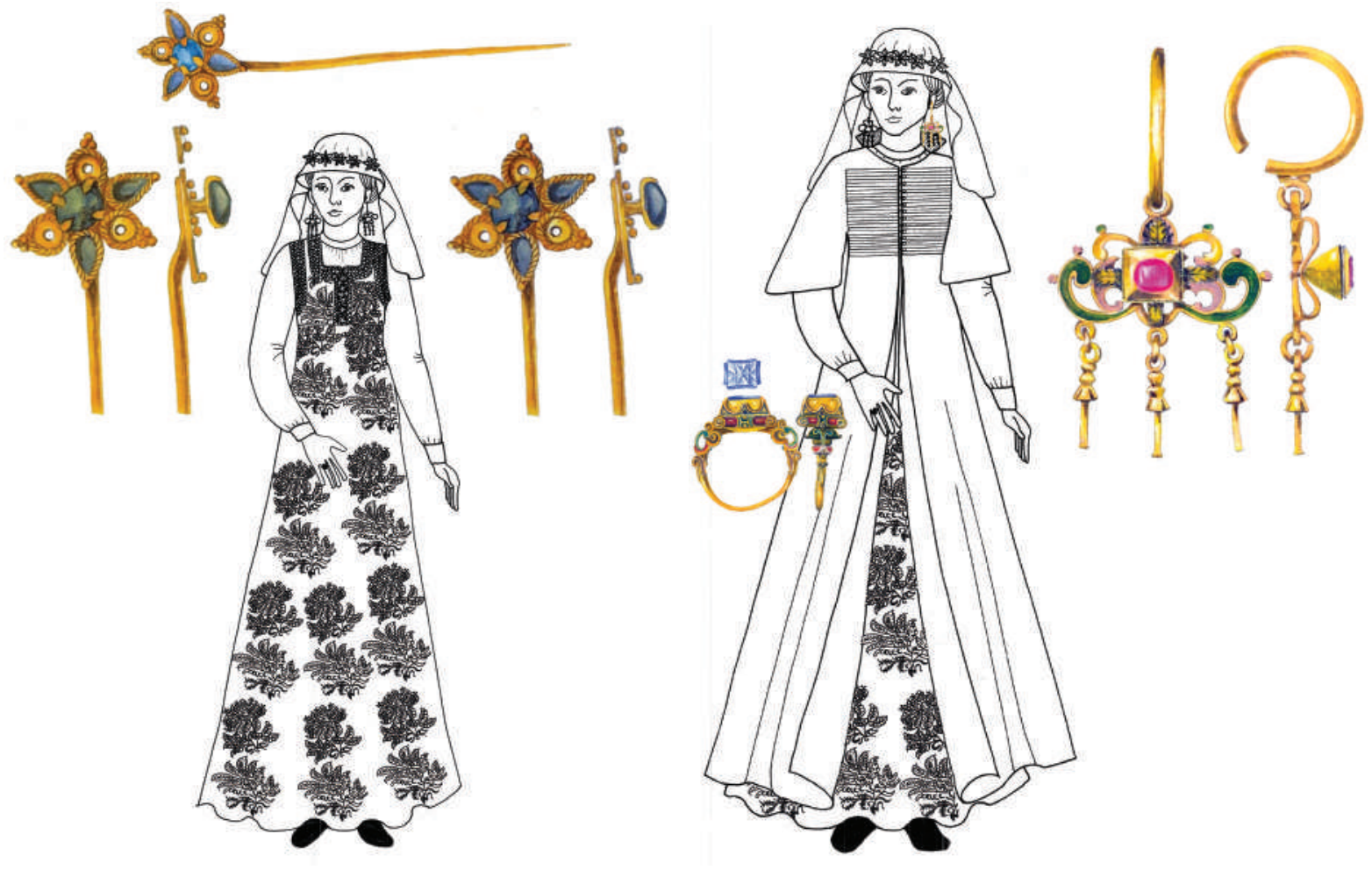

a

b
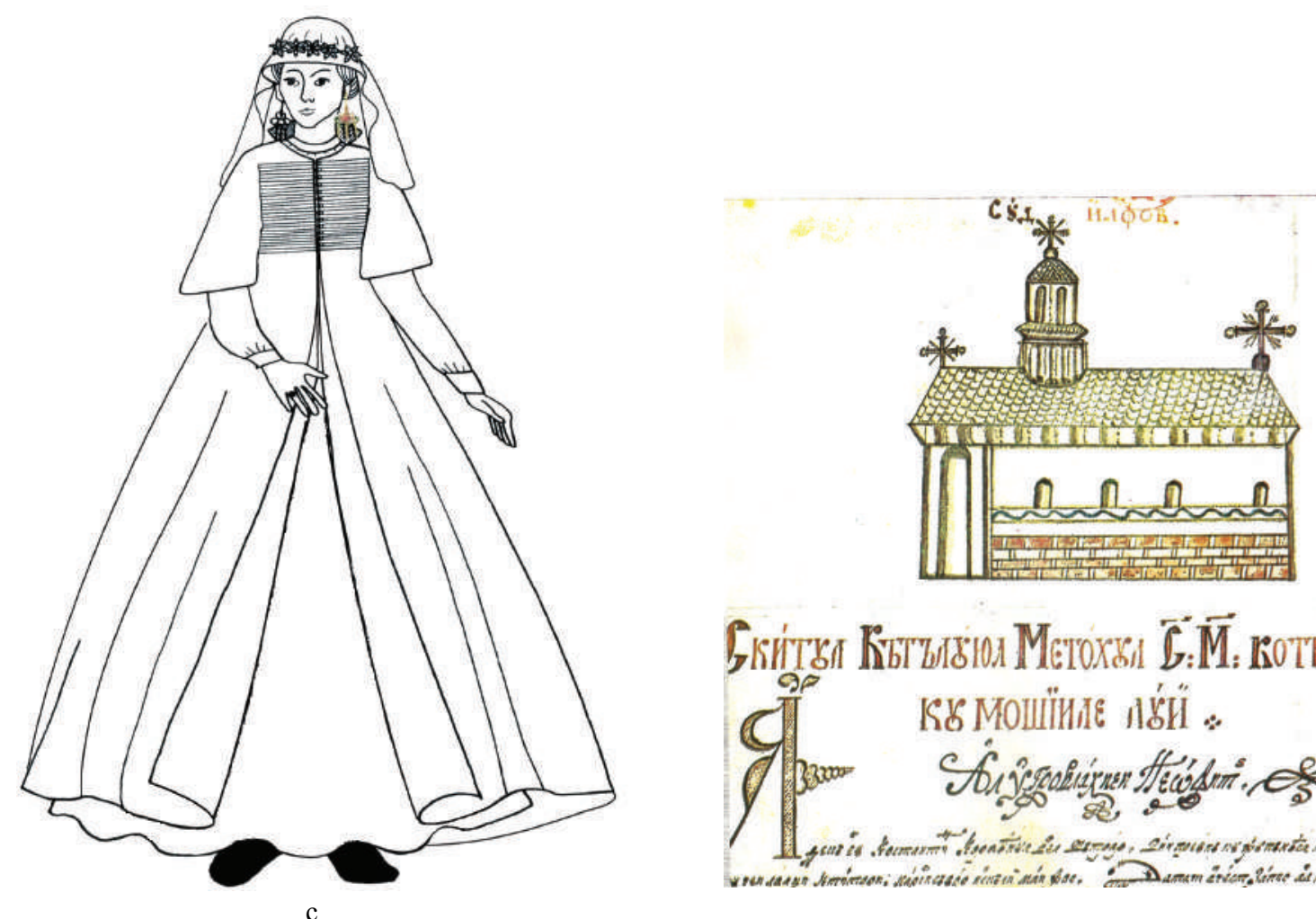

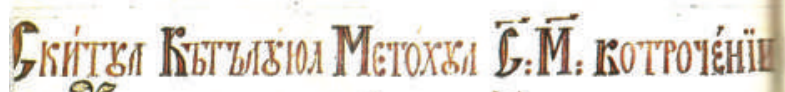

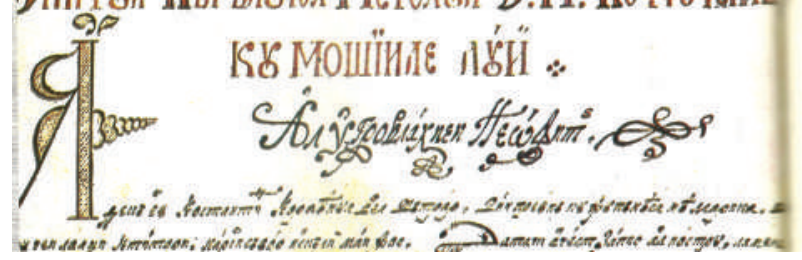

Figura 25. Propuneri de reconstituiri ale costumelor din cavoul 4: a - rochie şi ace de maramă; b - rochie, conteș, cercei şi inel; Figura 26. Biserica Mănăstirii Cătălui, desen de Dionisie Eclesiarhul (1802).

c - rochia fără imprimeu, dar mult evazată, conteș.

Desene: $\mathrm{a}-\mathrm{b}$ - Georgiana Ducman și Simona Movilă; c-Raluca Teodoru-Arnăutuu. 
În celelalte morminte (M. 3-7 cu pereți de cărămidă și M. 8-9 simple gropi) nu se știe pe cine au „odihnit”"19.

Prin urmare înmormântarea Mariei Corbeanu-Năsturel la Cătălui și nu la Herești este explicabilă.

De altfel distanța dintre Herești și Cătălui este de doar circa $20 \mathrm{~km}$, ea neconstituind un impediment la transportarea răposatei - doar dacă decesul n-a corespuns cumva cu o vreme neprielnică.

Nejefuirea acestui cavou 4 de la Cătălui, în februarie 1689, s-ar putea datora lipsei unei eventuale pietre de mormânt care să-i marcheze prezența. De altfel acoperirea lui cu o porțiune de pavaj în faza a III-a ne dovedește că în acea perioadă nu se mai cunoștea existența sa.

Nejefuite sunt și alte cavouri, care neavând pietre de mormânt pe ele li se uitase existența. Excepție face cavoul 6, al marelui ban Teodosie îngropat cu doi din fii săi. Probabil că piatra sa de mormânt, fiind foarte grea, n-a putut fi urnită ... a fost doar spartă.

În ceea ce privește persoana din cavoul nr. 3, aflat la vest de cavoul nr. 6 (marele ban Teodosie) și la nord de cavoul nr. 4 (Maria Corbeanu-Năsturel) - cavouri a doi frați - nu este exclus să fie ... Hrisosculina, a doua soție a primei persoane și cumnata celei de a doua ... Dar cine era această Hrisosculina, când a încetat din viaţă, încă nu se știe ... Ba mai mult, într-un document din 16 februarie 7155 (= 1647), deci din perioada când mai era în viaţă Teodosie, se spune „că soția banului Tudosie a dăruit Mănăstirii Sărindar 180 stânjeni de moșie în Roșiul”20. Adică, în documentele oficiale, nici măcar nu i se spune numele.

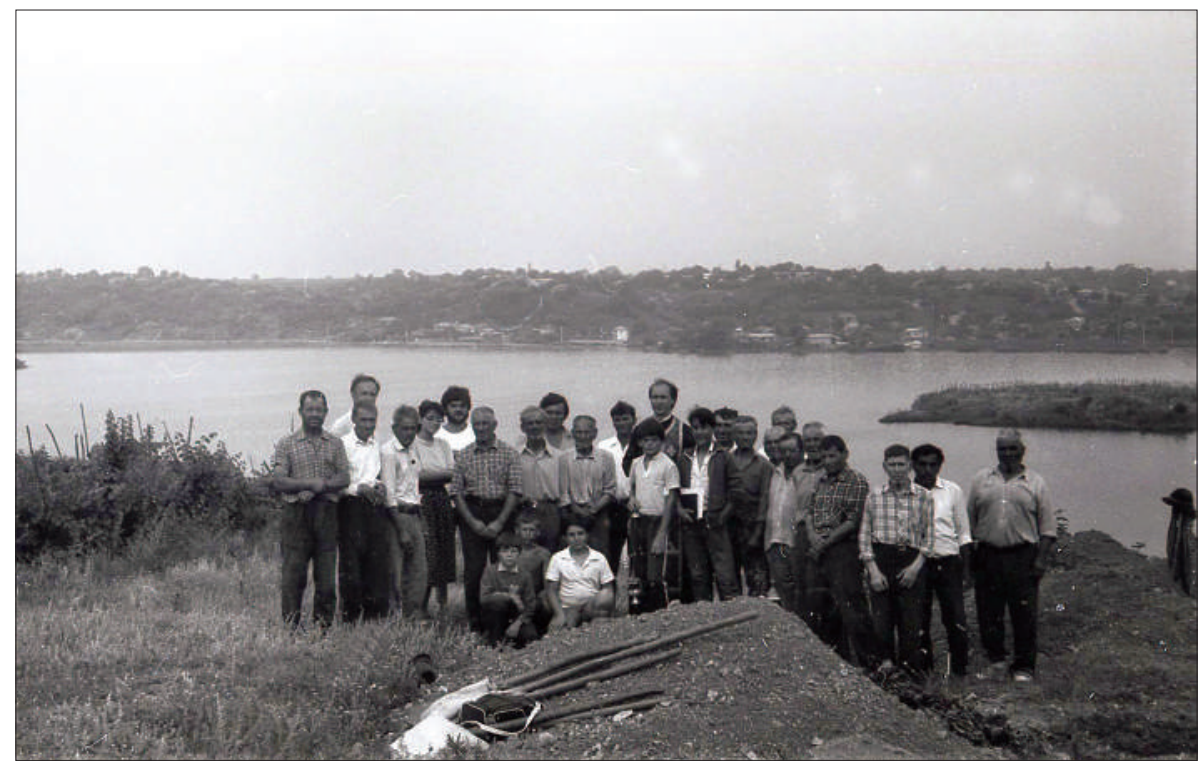

Figura 27. Ultima campanie arheologică, Cătălui 1988, cu preotul Aurel Cucută.

\footnotetext{
19 Informație Ion Șerban Chicideanu; Bătrîna 2017, 71-86 de unde am preluat toate cele consemnate mai sus.

20 Ciucă, Vătafu-Găitan 1983, doc. 746.
} 


\section{BIBLIOGRAFIE}

Cantacuzino, Trohani 1979

Trohani, Damian, Sârbu 1995

Cantacuzino, Gh., Trohani, G., Săpăturile arheologice de la Cătălui-Căscioarele, jud. Ifov, $C A$, III, 1979, 261-328.

Trohani, G., Damian, P., Sârbu, V., Nouvelles recherches archéologiques a Cătălui-Căscioarele, dép. de Călărași, Cultură și Civilizație la Dunărea de Jos, XIII-XIV, 1995, 233-257.

Theodorescu 1979

Theodorescu 1968

Theodorescu, R., Un monument medieval din Muntenia medievală: Cătăluiul, în Itinerarii medievale, Editura Meridiane, București, 1979, 168-179.

Theodorescu, R., Un monument uitat din Muntenia medievală: Cătăluiul, SCIA, Arta Plastică, 15, 1968, 2, 213-220.

Sturdza 2018

Cantacuzino, Bălan 1968

Elian et al. 1965

Sturdza, M. D., Familiile boierești din Moldova și Țara Românească. Enciclopedie istorică, genealogică și biografică, vol. V, Editura Corint, 2018, 257-271 (familia Corbeanu).

Cantacuzino, Gh., Bălan, C., Date noi pe marginea cercetărilor istoricoarheologice de la mănăstirea Cătălui, Revista Muzeelor, 5, 1968, 6, 547-553.

Elian, Al., (redactor responsabil), Bălan, C., Chircă, H., și Diaconescu, O., Inscripțiile medievale ale României, I, orașul București, Editura Academiei, 1965, 656-657, nr. 938.

Nicolescu 1970

Nicolescu, C., Costumul de curte în țările române, Editura Muzeul de Artă al R. S. România, București, 1970.

Constantinescu, Moisescu, Nicolăescu-Plopşor 1967

Constantinescu et al. 2008-2009

Constantinescu, N., Moisescu, Cr., Nicolăescu-Plopșor, D., Considérations sur les tombes princières de Târgovişste, Dacia, N.S. XI, 1967, 301-320.

Constantinescu, N. (coordonator), Ionescu, C., Diaconescu, P., Rădulescu, V., Târgoviște Reședința Voievodală (1400 - 1700). Cercetări arheologice (1961 - 1986), Editura Cetatea de Scaun, Târgoviște, 2008-2009.

Ilie 2010

Ilie, L. M., Matei Basarab și fiul său adoptiv (Mateiaș). Relație de familie sau relație politică ?, Analele Universității din Craiova, Seria Istorie, 15, 2010, 2 (18), 47-54.

Iorga 1905

Text preluat de pe https://audiotravelguide.ro/biserica-sf-voievozi-heresti, text mai apropiat de originalul în slavonă al pisaniei publicată de N. Iorga - Inscripții din bisericile României. Adunate, adnotate și publicate, I, București, 1905, 9091 , dar care dă o traducere aproximativă. Însă şi acest text folosește neologisme inadecvate ...

Bătrâna 2017

Bătrîna, A., Biserica familiei Năsturel din Herești (jud. Giurgiu). Cercetări arheologice, $\operatorname{SCIV}(A), 68,2017,1-4,71-86$.

Ciucă, Vătafu-Găitan 1983

Ciucă, M. D., Vătafu-Găitan, S., Catalogul documentelor Țării Românești din Arhivele Statului, VI, București, 1983, doc. 746, 285-286. 


\section{LISTE DES ILLUSTRATIONS}

Figure 1. Vue générale, de l'est vers l'ouest, du lieu où se trouvait le Monastère Cătălui. En plan lointain la commune Căscioarele, dép. Călărași. Au centre l'établissement néolithique Ostrovel. 25 avril 1965.

Figure 2. Plan d'ensemble de l'ancien Monastère Cătălui comme suite des fouilles archéologiques des années 19651968, 1977 et 1988.

Figure 3. Partie du sud de l'Eglise du Monastère Cătălui. Recherches automne 1965.

Figure 4. Requiem pour les fondateurs, pour ceux enterrés dans le cimetière des alentours de l'Eglise et pour ceux qui se sont donner la peine pendant les fouilles archéologiques. 16 novembre 1967.

Figure 5 a. Pierre tombale de Stan Spatar du caveau no. 1. 1967; b - fragments d'étoffe de la terre de remplissage.

Figure 6. Pierre tombale de Caplea. 1967.

Figure 7. a. Caveau no. 2, tombe d'un enfant, le fond du cercueil en bois de pin. 1967; b-c .morceaux de bois de pin du cercueil.

Figure 8. Caveau no. 5, pillé au moyen-âge. 1967.

Figure 9. Caveau no. 3. 1967.

Figure 10. Bague en or du caveau no. 3: a) face, b) dos, c) dessin (Helene Becheș, 1968)

Figure 11. a - Pierre tombale du grand ban Théodose Corbeano. Photo 1967; b - Pierre tombale du grand ban Théodose Corbeano. Dessin 1967.

Figure 12. Tombeau du grand ban Théodose Corbeano avec ses deux enfants Georges et Théodose. Caveau no. 6. 1988. Figure 13. Bague en or avec l'inscription Hrisosculina: a) chaton sigillé, b) profil longitudinal, c-d) profils transversaux (Musée Oltenița).

Figure 14. a-b - Bague-sceau de la Dame Tudosca (+1639), épouse du prince Basile Lupu.

Figure 15. a-b - Bague-sceau du Prince Jean, fils de Basile Lupu.

Figure 16. Calice en argent doré du Monastère D'un bois contenant une inscription de souvenir de Théodose et de Hrisosculina (Musée National d'Art de la Roumanie).

Figure 17. a - Tombeau no. 2 de l'intérieur de l'église. 1965; b - fragments d'étoffe avec des boutons en bronze du Tombeau No. 2 de l'église; $\mathrm{c}$ - ganse avec des paillettes de la Tombe 41; $\mathrm{d}$ - ganse avec des paillettes de la Tombe 42.

Figure 8. a-j - Caveau no. 4: a - avant l'ouverture; $\mathrm{b}$ - le contenu; $\mathrm{c}$ - la moitié supérieure du corps de la personne inhumée dans le caveau; $\mathrm{d}$ - le corsage de l'habit; $\mathrm{e}$ - le corsage de la robe; $\mathrm{g}-\mathrm{i}$ - fragments de l'habit; $\mathrm{j}$ - dessin archéologique des découvertes de l'intérieure du caveau.

Figure 19. Aiguilles du voile de tête du caveau no. 4.

Figure 20. Les boucles d'oreilles 1 et 2 du caveau no. 4: a) face ; b) dos; c) dessin (Helene Becheș, 1968).

Figure 21. Bague en or du caveau no. 4: a) profil oblique; b) profil oblique; c) profil; d) dos; e) dessin (Helene Becheș, 1968)

Figure 22. a-b - Boucle d'oreille de la Princesse Elina, Târgoviște.

Figure 23. Ressemblance de costumes: $\mathrm{a}$ - Voroneț; $\mathrm{b}$ - Dragomirna; $\mathrm{c}$ - felon; $\mathrm{d}$ - boutonnage d'habit Dragomirna; $\mathrm{e}$ - robe Dragomirna; $\mathrm{f}$ - corsage face, robe Dragomirna; $\mathrm{g}$ - corsage dos, robe Dragomirna.

Figure 24 a-d - Personnes portant des vêtements pareils: a1-2 - Mathieu Basarab et Princesse Elina, manuscrits d'époque; $b$ - Princesse Elina; c - Petit Mathieu, Tableau votif de l'Eglise du Monastère de Strehaia; d - pierre glissante du tombeau de Petit Mathieu.

Figure 25. Propositions de reconstitutions des vêtements du caveau no. 4: $a$ - robe et aiguilles de voile de tête; $b$-robe, habit, boucles d'oreilles et bague; $\mathrm{c}$ - robe sens imprimée mais bien évasée, habit. Dessins: $\mathrm{a}-\mathrm{b}$ - Georgiana Ducman et Simona Movilă; c - Raluca Teodoru-Arnăutu.

Figure 26. L'Eglise du Monastère Cătălui, dessin de Dionisio l'Ecclésiarque (1802).

Figure. 27. Les dernieres fouilles archelogiques, Cătălui 1988, avec le rev. pr. Aurel Cucută.

GEORGE TROHANI, 